\title{
SYNESTÉZIE V AUTORSKÝCH KNIHÁCH DAISY MRÁZKOVÉ
}

\author{
MARKÉTA ČEJKOVÁ \\ Ústav pro dějiny umění Filozofické fakulty Univerzity Karlovy \\ marketa-cejkova@email.cz
}

\begin{abstract}
Synaesthesia in the author's books of Daisy Mrázková

The paper focuses on books illustrated and written by the Czech artist Daisy Mrázková. It covers main inspirations and biographical information related to this segment of her artistic work. The paper is mainly focused on the gift of synaesthesia and its potential influence on Mrázková's books illustrations. The phenomenon of synaesthesia is explained on the ouevre of the foreign artists and writers. Further attention is paid to other Czech artists with synaesthesia.
\end{abstract}

Keywords: synaesthesia - author's book - book illustration - Daisy Mrázková's books synaesthetic perception of letters

\section{Úvod}

Daisy Mrázková nepatřila mezi všeobecně známé české umělce, na veřejnosti vystupovala zcela ojediněle a i její členství ve skupině UB 12 bylo nenápadně neobvyklé. Avšak pro čtenáře a milovníky umění, kteří si její dílo našli, otevírala každou svou autorskou knihou nový tajuplný prríběh přesahující každodenní rutinní život vyjádřený nejen písmem, ale i ilustracemi, jejichž barevná škála byla s textem nerozlučně svázána pravidly stanovenými neobvyklým darem, kterým byla Daisy Mrázková obdařena, a sice vrozeným specifickým a individuálním vnímáním barevnosti jednotlivých písmen abecedy, takzvanou synestézií. Př́běhy dětí a zviřat, které se v autorských knihách Daisy Mrázkové zhmotňovaly, mají $\mathrm{v}$ sobě zvláštní neurčitost, tajuplnost, nedořečenost a nechávají čtenáře domýšlet a dále obohacovat vyprávěný príběh o vlastní nápady a interpretace, podněcují jeho vlastní fantazii a kreativitu.

Padesátá a šedesátá léta prožila Daisy Mrázková v domácím prostředí, starala se o děti a domácnost, poskytovala zázemí svému muži, malíri Jiř́mu Mrázkovi, a tvořila pouze $\mathrm{z}$ vnitřní potřeby a nesystematicky. $\mathrm{V}$ padesátých letech, typických kolektivizací a sovětizací, ${ }^{1}$ nebyla Daisy Mrázková těmto vlivům ve svém uzavřeném prostředí prrímo vystavena, i když se jejich intenzivnímu šírení jistě nemohla vyhnout. Na její vnitřní svět, který se $\mathrm{v}$ šedesátých letech začal vyjevovat $\mathrm{v}$ jejích autorských knihách, neměla tato veřejná ideologická masáž žádný vliv. Daisy Mrázková nebyla omezena programem či reflexí

1 Jaroslav Pažout (ed.), Každodenní život v Československu 1945/8-1989, Praha 2015, s. 20-21. 
aktuální politické či životní situace, byla pro ni charakteristická názorová nezávislost a nepředpojatost a jasná preference „vnitřních ziskư nad vnějšími úspěchy“.2

Jistě významnou roli sehrálo i vlastní založení Daisy Mrázkové a její vnitřní síla. Byla spíše pasivní členkou skupiny UB 12 a její status v této skupině byl popsán následovně: „Představme si, že umělci skupiny UB 12 žijí společně ve velkém domě na pobřeži moře. $V$ takové situaci by Daisy Mrázkové nejspíše připadla mistnost v půdní mansardě, odkud by mohla pozorovat ptáky, slyšet vítr a sledovat mraky na obloze. Žila by zde nenápadně a poněkud samotářsky, jen občas by zašla na kávu, pohovořit si s ostatními členy UB 12. Měla by však nejkrásnější výhled. "3 Máme-li na paměti tuto charakteristiku Daisy Mrázkové při čtení jejích autorských př́iběhů, nemůže nás nikterak překvapit jejich nedořečenost, otevřenost, prostor pro vlastní interpretaci, poklidné tempo a stručné, výstižné, dobře promyšlené vyjadřování jejich hrdinů.

Dílo Daisy Mrázkové, které zahrnuje kromě autorských knih i ilustrace a volnou kresebnou a malíŕskou tvorbu, nebylo dosud monograficky zpracováno. Následující text se primárně zabývá fenoménem autorské knihy Daisy Mrázkové a možným vlivem jejího synestetického vnímání na tuto část její výtvarné tvorby.

Použité zdroje jsou různorodé, zahrnují především českou a zahraniční odbornou uměleckohistorickou literaturu, ale vzhledem $\mathrm{k}$ již zmíněné dosavadní absenci podrobné monografie díla Daisy Mrázkové i zdroje z denního či občasného tisku, z internetu či televizního a rozhlasového vysílání. Při zkoumání problematiky synestézie byla využita i zahraniční odborná literatura v oblasti neurologie. Osobně jsem se s Daisy Mrázkovou setkala při delším rozhovoru v jejím bytě v Nuslích na podzim roku 2015, ale vzhledem $\mathrm{k}$ jejím tehdejším zdravotním potížím s pamětí jsem $\mathrm{k}$ podrobnostem $\mathrm{z}$ jejího díla či života př́liš nových informací nepřidala.

\section{Autorské knihy Daisy Mrázkové}

Daisy Mrázková napsala a zároveň vlastními ilustracemi doprovodila dvanáct autorských knih uvedených v Tabulce 1.

Tabulka 1: Přehled autorských knih Daisy Mrázkové:

\begin{tabular}{|l|l|}
\hline Název knihy & První vydání \\
\hline & (vydáno v SNDK4/ Albatrosu) \\
\hline Neplač, muchomůrko & 1965 \\
\hline Chlapeček a dálka & 1969 \\
\hline Byla jedna moucha & 1971 \\
\hline Haló, Jácíčku & 1972 \\
\hline Neposlušná Barborka & 1973 \\
\hline
\end{tabular}

Jaromír Zemina, Via artis, via vitae, Praha 2010, s. 321.

Milena Slavická, UB 12 - studie, rozhovory, dokumenty, Praha 2006, s. 55.

SNDK - Státní nakladatelství dětské knihy, od roku 1969 nakladatelství Albatros. 


\begin{tabular}{|l|l|}
\hline Můj medvěd Flóra & 1973 \\
\hline Auto z pralesa & 1977 \\
\hline Nádherné Úterý čili slečna Brambůrková chodí po světě & 1977 \\
\hline Kluk s mičem & 1978 \\
\hline Co by se stalo, kdyby... & 1980 \\
\hline Slon a mravenec & 1982 \\
\hline Písně mravenčí chůvy & 2009, vydal Baobab \\
\hline
\end{tabular}

Daisy Mrázková se považovala především za maliřku, ale s literárními pokusy experimentovala od mládí. ${ }^{5}$ Sama k nim však byla hodně př́ísná, nemluvila o nich jako o psaní, ale o „škrábání, a považovala je za hodně patetické a sentimentální. ${ }^{6}$ Až v okamžiku, kdy se jí podařilo psaní zestručnit, zjednodušit a vnést do něj i smích, odvážila se autorsky vyjít na veřejnost, ${ }^{7}$ a to knížkami určenými dětskému čtenáři a posluchači.

První autorské knihy Daisy Mrázkové začaly vycházet na začátku šedesátých let 20. století, tedy v období po určitém politickém tání na přelomu padesátých a šedesátých let, v němž nová generace mladých autorů začala dosud vyžadovaný socialistický realismus a důraz na děj nahrazovat prosazováním fantazie, vykreslováním atmosféry vyprávěných př́iběhů a místo suchého popisu pracovala s náznaky a symboly. ${ }^{8}$ Bezesporu důležitý byl i mezinárodní úspěch Státního nakladatelství dětské knihy na Expo'58 v Bruselu, kde jako jediné nakladatelství získalo Grand Prix. ${ }^{9}$

První autorskou knihou Daisy Mrázkové nebyla její oficiálně uváděná prvotina $\mathrm{Ne}$ plač, muchomůrko, nýbrž knížka, kterou napsala a nakreslila pro své děti jako jejich první učebnici angličtiny. Daisy Mrázková chtěla vytvořit učebnici neobvyklou, která se nezabývá pouze jazykem, ale jeho učení skrývá do zábavného příběhu o lesních zviŕátkách a Haničce Myslivcové, holčičce z myslivny. Hlavními zvírecími hrdiny jsou zajíček Jácek, veverka Veverka, srnka Zizinka a medvěd Brumla, jejich učitel v lesní škole. Daisy Mrázková umístila své postavy do oblíbeného lesního prostředí a zajíc a veverka jsou hlavními hrdiny také pozdější autorské knihy Haló, Jácíčku.

Učebnice obsahuje celkem deset kapitol rozdělených do několika částí: úvodní text, slovíčka, mluvnice a cvičení a jako poslední je v učebnici uveden delší příběh: Příběh na rozloučenou („Good-bye story“). Každá kapitola je doprovázena drobnými ilustracemi nejprve načrtnutými tužkou a dokončenými pomocí pastelek či výjimečně vodovými barvami. Ilustrace uvozující každou kapitolu je umístěna v rámečku, další barevné ilustrace pak doplňují volně text kapitoly. [obr. 1] Při vysvětlování některých mluvnických jevů použila Daisy Mrázková i drobné perokresby či tužkové kresby zejména lidských postav, nakreslené jen několika málo výstižnými tahy. Ilustrace Př́běhu na rozloučenou jsou pouze načrtnuty tužkou, nejsou dokončeny v barvě.

5 Viz Slavická (pozn. 3), s. 212.

Ibidem, s. 212.

Ibidem, s. 212.

8 Blanka Stehlíková, Od seriálu k autorské dětské knížce, in: Blanka Stehlíková - Věra Vařeková - Ondřej J. Sekora, Ondřej Sekora - Práce všeho druhu, osobnost a dílo, Praha 2003, s. 147.

9 Ibidem, s. 147. 
Texty jednotlivých kapitol předjímají autorské knihy Daisy Mrázkové svou lapidárností, danou i účelem učebnice, a nenápadným morálním poselstvím o významu přátelství, a to zejména v Př́běhu na rozloučenou.

Autorské knížky Daisy Mrázkové nebyly primárně určeny jejím dětem, protože $\mathrm{v}$ době, kdy začaly tyto př́běhy vycházet, bylo dceři Veronice dvacet a synovi Cyrilovi šestnáct let, i když jistě své vlastní mateřské zkušenosti a instinkty nemohla jako jeden ze zásadních zdrojů inspirace vynechat.

První autorskou knížkou, kterou jí Státní nakladatelství dětské knihy ${ }^{10}$ v roce 1965 vydalo, byla knížka původně šesti krátkých pohádek o holčičce Kateřince Neplač, muchomůrko. Vydání této autorské knížky navázalo na ilustrace Malenky a štětce, na níž pracovala s redaktorkou Albatrosu Olgou Krejčovou, ${ }^{11} \mathrm{k}$ vydání ji však připravil redaktor Karel Černý, ${ }^{12}$ který přijal i další Kateřininy př́iběhy, jež Daisy Mrázková k prvním šesti doplnila a rozšíríla jejich počet na dvacet dva. Původním šesti pohádkám o Kateřině ř́kala Daisy Mrázková pohádky z myslivny a k jejich sepsání ji inspiroval rozhlasový pořad Hajaja, ${ }^{13}$ který se začal vysílat 2 . ledna 1961 v Československém rozhlase a jemuž propůjčil svůj hlas herec Vlastimil Brodský. ${ }^{14}$ Původně je Daisy Mrázková sepsala bez výhledu na jejich publikování pro své děti, ale právě v rozhlase byla zveřejněna výzva, aby autoři zasílali své pohádky, které by rozhlas mohl vysílat. ${ }^{15}$ Daisy Mrázková své pohádky do rozhlasu zaslala. Po jejich původním přijetí jí ale bylo později oznámeno, že pohádek $s$ těmito náměty již mají dostatek a nemají pro ně použití.

Až po spolupráci s Olgou Krejčovou na Malence a štětci jí umělkyně šest pohádek o Kateřině nechala posoudit, a to konečně s kladným výsledkem. Po redakčních úpravách byla kniha vydána $\mathrm{v}$ edici Sedmikrásy určené dětem od čtyř let, pod plným názvem Neplač, muchomưrko (malá knižka o velkých věcech).

Kateřininy př́běhy se odehrávají $\mathrm{v}$ lese $\mathrm{v}$ okolí myslivny, kde žije se svými rodiči, a v př́bězích vystupují lesní zvířata mluvící lidskou řečí. V této knížce se také poprvé objeví postava zajíčka Jácíčka, který je hrdinou jedné z dalších autorských knih Daisy Mrázkové.

Druhou vydanou autorskou knihou Daisy Mrázkové je titul Chlapeček a dálka z roku 1969, sbírka jednotlivých pohádek, které nebyly vhodné do její prvotiny. Hlavním hrdinou je $\mathrm{v}$ nich malý chlapec, který žije sám $\mathrm{v}$ malém domku a zažívá různá fantastická dobrodružství. I v této knize je pro př́iběhy zcela klíčová okolní př́roda.

Třetí autorskou knihou je vyprávění o každodenních zážitcích holčičky Helenky a mouchy Rudolfíny Byla jedna moucha z roku 1971. Vystupují zde dvě rovnocenné hlavní postavy, které si spolu o svých společných zážitcích povídají. Daisy Mrázková tuto autorskou knihu považovala za př́liš nabádavou, nazývala ji „sondou do dětstvi “ ${ }^{\text {“16, }}$, redaktor Karel Černý ji zase považoval za př́liš pedagogickou ${ }^{17}$.

10 http://www.slovnikceskeliteratury.cz/, vyhledáno 1. 6. 2017.

11 Viz Slavická (pozn. 3), s. 212.

12 Ibidem, s. 213.

13 Ibidem, s. 212.

14 http://www.pribehrozhlasu.cz/odhaleni-89+1/slavne-porady/2804982, vyhledáno 1. 6. 2017.

15 Viz Slavická (pozn. 3), s. 212.

16 Viz Slavická (pozn. 3), s. 213.

17 Ibidem, s. 213. 
Na tuto drobnou výtku reagovala Daisy Mrázková svou další autorskou knihou Haló, Jácíčku, která měla být pravým opakem, knihou plnou bláznivých dobrodružství, která spolu zažívají malá veverka a zajíček Jácíček. Její podtitul zněl Knižka o velikém přátelství.

V̌̌echny tyto čtyři autorské knihy se odehrávají v př́rodě, v českém prostředí, často ve smrkovém lese ${ }^{18}$ plném zvírat a prostém nebezpečí. Hlavními postavami jsou malé děti a mluvící zvířata, která ve většině případů personifikují přátele hlavních dětských postav či jako v př́padě Jácíčka a jeho kamarádky veverky jsou sama hlavními hrdiny. Toto přátelské prostředí českého lesa bylo Daisy Mrázkové velmi blízké. Na podzim roku 1944 musela ona i její budoucí manžel, stejně jako jejich spolužáci v dalších ateliérech UMPRUM, přerušit svá studia. Daisy Troníčková se stala Daisy Mrázkovou a odjela s manželem Jiřím do Březin, malé vesničky na pomezí Vysočiny a Pardubického kraje v hlubokých lesích, kde společně prožili v malé chaloupce období až do května 1945, ukryti před pracovním úřadem. ${ }^{19} \mathrm{Na}$ Vysočinu pak Mrázkovi jezdili dlouhá léta i se svými dětmi ${ }^{20}$ a toto přátelské a známé prostředí se promítlo i do prvních autorských knih Daisy Mrázkové.

V roce 1973 vyšla Daisy Mrázkové další autorská kniha Neposlušná Barborka, která vznikla na objednávku redakce Albatrosu na knížku o barvách ${ }^{21}$ pod redakčním vedením Olgy Štruncové. ${ }^{22}$ Neposlušná Barborka představuje významnou změnu v podobě autorských knih Daisy Mrázkové, protože je první skutečně obrázkovou knihou ve smyslu v němčině používaného termínu Bilderbuch, pro jehož podobu je typická převaha obrazové formy před formou textovou. Ilustrace typicky zabírají v knize celé stránky a text je velmi stručný a využívají se v něm krátká a jednoduchá slova, aby si je začínající čtenář dokázal snadno přečíst a malý posluchač zapamatovat. Text bývá bud' vložen do vlastní ilustrace jako v př́padě Neposlušné Barborky nebo je umístěn na samostatnou stránku jako v chronologicky další vydané a zřejmě nejznámější autorské knize Daisy Mrázkové Můj medvěd Flóra.

Tato knížka vydaná v roce 1973 stejně jako Neposlušná Barborka znamená i předěl ve výtvarné technice používané Daisy Mrázkovou v autorských knihách. Poprvé se v ní objevuje drobná perokresba, která zatím zůstává oddělena od celostránkových kvašů a odráží se od bílého pozadí jako doprovod textů. Medvěd Flóra je skutečný plyšový medvídek, nalezený synem Daisy Mrázkové Cyrilem v parku a opatrovaný rodinou do dnešního dne. Příběh jeho záchrany a proměny líčí Daisy Mrázkové ve své autorské knize, jen svého tehdy osmnáctiletého syna promění v šestiletého Petra.

Následující Auto z pralesa je sledem nesouvisejících pohádek sepsaných v dřivějších letech s různými hlavními postavami a vymyká se $\mathrm{z}$ bilderbuchové podoby, na rozdíl od dalších tří klasických autorských pohádek Daisy Mrázkové, a sice titulů Nádherné Úterý čili slečna Brambưrková chodí po svètě, Co by se stalo, kdyby... a Slon a mravenec.

Hlavní postavou v Bilderbuchu Nádherné Úterý čili slečna Brambiorková chodí po svètě je úterní den v týdnu, jenž vypráví staré paní v parku příběh její ztracené panenky, kterou

18 Ibidem, s. 213.

19 Ibidem, s. 212.

20 Osobní sdělení Daisy Mrázkové.

21 Ivo Fencl, Daisy Mrázková - renesanční autorka knih pro děti, www.citarny.cz, 14. 9. 2014, nepag.

22 Daisy Mrázková, Neposlušná Barborka, Praha 1973, nepag. 
jí ušila v dětství její maminka a která spustila řetězec pozitivní energie a inspirace v životě různých lidí pokračující až do současnosti.

Co by se stalo, kdyby... nemá souvislý př́iběh, je to sbírka realistických i fantazijních otázek a stručných odpovědí, které mají inspirovat jejich čtenáře a posluchače k vymýšlení vlastních odpovědí a možná i dalších otázek. Otázky tedy oscilují mezi běžnými životními situacemi od Co by se stalo, kdyby přijel dědeček? nebo Co by se stalo, kdybych šel $v$ dešti do lesa bez kabátu? až po otázky povzbuzující dětskou imaginaci jako Co by se stalo, kdyby po Praze chodil obr? Daisy Mrázková tuto knížku psala se záměrem společného čtení rodičů a dětí, tedy prohlížení obrázků a povídání si, „výchově ke čtenářstvi" ${ }^{23}$.

Slon a mravenec je Bilderbuch s větším podílem textu než ty předchozí a vypráví o soužití veverky s mravencem a slonem, o jejich odlišnostech, které by je měly teoreticky oddělovat a znemožňovat jejich soužití a přátelství, ale které se v příběhu ukáží jako důležité, a vedou děti k toleranci a pochopení svého okolí.

Daisy Mrázkové vydala ještě před Slonem a mravencem $v$ roce 1978 opět pod redakčním vedením Olgy Štruncové autorskou knihu Kluk s míčem, v níž opustila formu Bilderbuchu a napsala dlouhý př́běh o klukovi Pepíkovi a jeho míči Trofině, naprosto výjimečně v její literární tvorbě psaný ich formou.

Je velmi obtížné přesně určit pro jakou věkovou kategorii čtenářů či posluchačů jsou autorské knihy Daisy Mrázkové vlastně určeny. Daisy Mrázková některé své autorské knihy tvořila pro prŕležitosti společného čtení rodičů či prarodičů a dětí nebo vnoučat, a proto lze $\mathrm{v}$ příbězích hledat nejen příběh a poučení pro dětské čtenáře a posluchače, ale i prostor pro fantazii, odpočinek a zamyšlení dospělých čtenářů, jejichž zážitek se umocňuje hlasitým čtením a společným emocionálním zážitkem s vlastními potomky.

Autorské knihy Daisy Mrázkové vycházely ve svých prvních vydáních v období od roku 1965 do roku 1982. Až po dlouhých letech a po pádu socialistického režimu vydalo nakladatelství Baobab v roce 2009 Daisy Mrázkové další autorskou knihu Písně mravenčí chưvy ${ }^{24}$ obsahující šestnáct krátkých básní pro děti, které byly napsány už v šedesátých letech a rozšiřují tak její literární texty o básnický žánr. Knihu doprovázejí pestré celostránkové ilustrace vytvořené technikou akvarelu, kvaše a rozmývaných pastelek, jež Daisy Mrázková v posledním období své tvorby velmi originálně používala. Kniha byla vydána v grafické úpravě Heleny Šantavé. ${ }^{25}$

Je nutné ještě uvést další dvě autorské knihy, které nebyly nikdy vydány, a to knihu Lemuria na dosah z roku 1966 a knihu Kateřina nemá dlouhou chvíli, časově zařazenou do období po vydání autorské knihy Můj medvěd Flóra, tedy po roce 1973. Tyto dvě autorské knihy jsou uvedeny v katalogu z výstavy Daisy Mrázková dětem uskutečněné v dubnu 2001 v Galerii moderního umění v Roudnici nad Labem. ${ }^{26}$ Ilustrace k nerealizované knize Kateřina nemá dlouhou chvíli byly vystaveny v galerii Villa Pellé v rámci výstavního projektu Co by se stalo, kdyby..., který byl připraven kurátory Janem Rousem, Helenou Šantavou a Klárou Voskovcovou a probíhal od 22. listopadu 2017 do 28. ledna 2018. ${ }^{27}$

${ }^{23}$ Viz Fencl (pozn. 21), nepag.

24 Daisy Mrázková, Písně mravenčí chiovy, Praha 2009.

25 Ibidem.

${ }^{26}$ Miroslava Hlaváčková, Olga Karlíková, Louny 2001, nepag.

27 https://villapelle.cz/galerie-villa-pelle/archiv-vystav/vystava-daisy-mrazkova/, vyhledáno 20. 12. 2019. 


\section{Fenomén synestézie}

Daisy Mrázková dostala do svého života zvláštní a pro výtvarnou a literární umělkyni velice specifický dar, který její ilustrační tvorbu bez jakýchkoli pochybností naprosto zásadně ovlivnil. Tímto darem bylo jednoznačné propojení jednotlivých písmen abecedy s konkrétní barvou - synestézie.

Synestézie, $\mathrm{v}$ českém prostř̌edí doposud nepř́iliš známý a odborně či populárně málo popsaný jev, je neurologický fenomén, při němž podnět, který zapůsobí na jeden z lidských smyslů, ve stejném okamžiku vyvolá reakci dalšího z lidských smyslů. Vlastní slovo synestézie lze rozdělit do dvou částí pocházejících z latiny, a sice esthesia = vnímání a $s y n=$ zároveň ${ }^{28}$ Zajímavé je, že v souvislosti se synestézií se většinou mluví o neurologickém defektu, tedy poruše v negativním slova smyslu, přestože synestézie přispívá k pestřejěímu vnímání a obohacení vnitřního života, zejména umělcư, ${ }^{29} \mathrm{a}$ tedy i Daisy Mrázkové.

Synestézie spojuje dva různé vjemy, nejčastějš́ je spojení barvy a písmen, číslic nebo hudby, ale může se jednat i o chutě nebo hmatové vjemy. ${ }^{30}$ I spojení barev a písmen je individuální, dokonce sourozenci mohou mít písmena spojená s jinou barvou. ${ }^{31}$

Zásadní je pochopení, že synestézie není asociací, ale vjemem, který zároveň oslovuje dva či více smyslů. ${ }^{32}$ Rozdíl mezi asociací a synestézií byl již experimentálně potvrzen. ${ }^{33}$ Nedávné vědecké výzkumy však potvrzují, že rozvoj synestézie může být umocněn právě asociacemi používanými v procesu učení, ${ }^{34}$ zejména u dětí těsně předškolního a raného školního věku, $v$ němž je nejčastěji synestetické vnímání u člověka rozpoznáno. ${ }^{35}$

Vědecký výzkum synestézie je poměrně mladou disciplínou ${ }^{36}$ a zatím přináší spíše otázky než odpovědi, ale pro pochopení tohoto fenoménu jistě velmi zásadního pro unikátní propojení ilustrace a slova v autorských knihách Daisy Mrázkové je nutné fenomén synestézie blíže objasnit.

Výzkumy posledních let prokazují, že novorozenci vnímají okolní svět jako celek, nerozlišují mezi světlem, zvukem či chutí. ${ }^{37}$ Pro dospělé je nejbližší tomuto způsobu vnímání asi nejvíce propojené současné vnímání chuti a čichu, o jehož propojení se nejvíce dozvíme ve chvíli, kdy máme silnou rýmu a vnímání jídla je omezené. ${ }^{38}$

Tento způsob vnímání se postupně mění, jak se vyvíjejí smysly novorozenců. Společně s vývojem smyslů se mění i způsob mozkové činnosti. V mozku novorozence není žádný předem daný systém; zjednodušeně se dá říci, že se všechny vjemy dotýkají všech

\footnotetext{
${ }_{28}$ Cretien Van Campen, The Hidden Sense, Synesthesia in Art and Science, Massachusetts 2010, s. 1.

29 Ibidem, s. 1.

30 Ibidem, s. 2.

31 Ibidem, s. 4.

32 Ibidem, s. 4.

3 Ibidem, s. 5.

34 Marcus R. Watson - Jan Chromý - Lyle Crawford - David M. Eagleman - James T. Enns - Kathleen A. Akins, The prevalence of synaesthesia depends on early language learning, Consciousness and Cognition, č. 4, 2017, s. 214 (http:/ucjtk.ff.cuni.cz/wr-content/uploads/sites/57/2015/11/Watson-at-alprevalence-of-synaesthesia.pdf).

35 Ibidem, s. 214.

36 Ibidem, s. 213.

37 Viz Van Campen (pozn. 28), s. 29.

38 Ibidem, s. 29.
} 
receptorů a každý vjem je současně vnímán všemi smysly. ${ }^{39}$ Jakmile se začnou smysly specializovat na určité oblasti vnímání, jsou nevyužívaná nervová spojení deaktivována, a takto se od sebe postupně vnímání jednotlivými smysly odděluje. ${ }^{40}$ Předpokládá se, že většina vzájemných propojení je přerušena během prvního půl roku života a systém je uzavřen do jedenácti let věku. ${ }^{41}$

Na základě závěrů vědeckých experimentů se předpokládá, že nervová propojení mezi smysly nejsou nikdy zcela přerušena. Jejich dočasnou aktivaci potvrdily experimenty s LSD. ${ }^{42}$

Lze tedy konstatovat, že synestétem se rodíme všichni, ale většina $\mathrm{z}$ nás o tyto schopnosti přijde během prvního roku života. ${ }^{43} \mathrm{I}$ ti, kterým synestézie přetrvá do dalšího života, však již vnímají jinak než novorozenci, protože vnímají jednotlivými smysly, a nikoli všemi smysly najednou, a kromě běžného vnímání jednotlivými smysly jsou obdařeni vjemy, které přicházejí z několika vzájemně propojených smyslových zdrojů.. ${ }^{44}$

\section{Synestetické vnímání Daisy Mrázkové}

Většina synestétů objeví své specifické vnímání v době školní docházky, kdy se učí číst a psát a reflektovat své vnímání. ${ }^{45} \mathrm{~V}$ odborné uměnovědné literatuře není synestézie Daisy Mrázkové popsána či analyzována, ona sama se o ní v poskytnutých rozhovorech nezmiňuje. $\mathrm{V}$ době, kdy si děti se synestetickým vnímání tento dar začínají uvědomovat, řešila však Daisy Mrázková své začlenění do školního kolektivu kvůli svým nikoli zcela dostatečným vyjadřovacím schopnostem v českém jazyce způsobeným zřejmě poměrně uzavřenou domácností. Sdílela ji se svou rozvedenou anglickou maminkou, která češtinu nikdy dobře neovládla, a asi nelze očekávat, že by, ve věku, v němž je pro děti zásadní zařadit se do kolektivu a splynout s ním, ${ }^{46}$ chtěla ventilovat svůj nestandardní způsob vnímání. Tento postoj se pak i s ohledem na její introvertní povahu zřejmě v průběhu jejího života nijak zásadně nezměnil a o své specifické vnímání se podělila až v katalogu Horácké galerie, ${ }^{47}$ který byl vydán jen v malém nákladu. Vzhledem k dosavadní absenci její monografie je tak povědomí o její synestézii, stejně jako o vlastním fenoménu synestézie v České republice, jen marginální.

U Daisy Mrázkové se synestézie projevovala barevným viděním písmen. Každé písmeno mělo svou specifickou barvu, některé barvy byly spojeny s více písmeny najednou.

Přehled písmen abecedy a s nimi spojených barev specifických pro Daisy Mrázkovou je uveden v následující Tabulce 2:

39 Ibidem, s. 30.
40 Ibidem, s. 31.
41 Ibidem, s. 31.
42 Ibidem, s. 32.
43 Ibidem, s. 32.
44 Ibidem, s. 33.
45 Ibidem, s. 34.
46 Ibidem, s. 161.
47 Daisy Mrázková, katalog Horácké galerie, Nové Město na Moravě 2003, nepag. 
Tabulka 2: Synestetické propojení písmen a barev Daisy Mrázkové:

\begin{tabular}{|l|l|}
\hline Barva $^{48}$ & Písmeno abecedy ${ }^{49}$ \\
\hline šedá (od nejtmavější po nejsvětlejší) & $\begin{array}{l}\text { V, Y, X, O, S } \\
\text { P (nudně šedé) } \\
\text { R (není jednolité, ale složené z mnoha č́steček, asi } \\
\text { jako hrst brokŭ) }\end{array}$ \\
\hline skleněná & $\begin{array}{l}\text { G (nahnědlé) } \\
\text { J (jasnějśí) } \\
\text { A, I (chladnější) } \\
\text { U }\end{array}$ \\
\hline fialová & B, F (teplejší) \\
\hline zelená & $\begin{array}{l}\text { L (vodově) } \\
\text { T, E (světle) })\end{array}$ \\
\hline žlutobílá & C (někdy až bílá) \\
\hline oranžová & N \\
\hline červená & M \\
\hline cihlová & H \\
\hline hnědá & K (nudně hnědá) \\
\hline vodová & W \\
\hline rezavá & Z \\
\hline zároveň světle šedá i tlumené cihlová, asi jako & CH \\
\hline poloprưsvitný křemen & D, Q \\
\hline chybějící písmena v katalogovém přehledu & \\
\hline
\end{tabular}

Tento přehled uváděný Daisy Mrázkovou je založen na úplném výčtu písmenek latinské abecedy, s výjimkou písmen $\mathrm{D}$ a Q, avšak barevné vidění není provázáno s diakritikou

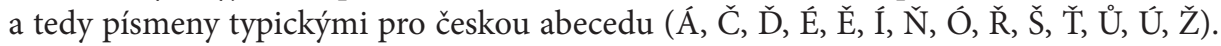
Daisy Mrázková neměla synesteticky propojené vidění pouze s českým jazykem, ale toto vidění mohlo být jednoduše propojeno s jinými cizími jazyky a jak se u ní pochopitelně nejvíce nabízí, zejména s angličtinou. O této skutečnosti u Daisy Mrázkové však chybí jakákoli svědectví.

Přehled písmen a s nimi spojených barev nezahrnuje všechny barvy a odstíny barevného spektra. Daisy Mrázková v takových případech doplňuje barvu do textu přímo jejím slovním popisem. ${ }^{50}$

Sama Daisy Mrázková v útlém katalogu ke své výstavě v Novém Městě na Moravě z roku 2003 své barevné vidění písmen a slov alespoň stručně popisuje. Při skládání písmen do slov je pro barevné vidění slova rozhodující především první písmeno slova, ale svou roli plní i další písmena ve slově použitá. ${ }^{51}$ Tento princip je popsán i v odborné literatuře jako typický pro synestéty, barevnost slova není složená z barev jednotlivých písmen. ${ }^{52}$

48 Ibidem, nepag.

49 Ibidem, nepag.

50 Ibidem, nepag.

51 Ibidem, nepag.

52 Jan Chromý, Synestézie a její lingvistické aspekty, Československá psychologie, č. 54, 2010, s. 386. 
Rozhodující při psaní autorských knížek je především obraz, tedy barvy, které Daisy Mrázková vidí, když si představí prostředí, ve kterém se děj odehrává, ${ }^{53}$ a další detaily. Takto jsou určena převládající písmena, která mají být v textu použita. Avšak v umění i v životě není nic jednoznačné. Stejně tak sama Daisy Mrázková uvádí, že někdy píše své texty opačně, viděný obraz či barevnost pak není primární, jsou určeny až použitými písmeny $\mathrm{v}$ textu. ${ }^{54}$ Jsou také situace, $\mathrm{v}$ nichž nelze nalézt slovo zkombinované $\mathrm{z}$ písmen odpovídajících barevné představě, a v těchto případech se Daisy Mrázková přikloní, byt’ nerada, $\mathrm{k}$ významu slova ${ }^{55}$ tak, aby text byl čtenáři dobře srozumitelný.

Nejnázornější je uvést př́íklad, který Daisy Mrázková pro pochopení svého vidění a stylu práce $\mathrm{v}$ autorských knihách sama použila:

„Tak například, když chci vylíčit suchý les plný praskajících větviček (mám přesnou představu o tom místě, byla jsem tam), použiji slov světlešedých, též několik tmavošedých, hnědošedých a modrošedých. Takových slov je množství, vybírám tedy podle významu, aby to bylo srozumitelné: $P, V, K, R, S, O$.

POROST, SUCHÝ POROST, PRASKOT, PRACH, VĚTVE, VESKRZE, KÜRA, CHRASTÍ, PAL̆EZ, PAVOUCI, SUK...

Napišu třeba: VYPRAHLÉ VĚTÉVKY PRASKALY nebo POLOVYSOKÉ VYSCHLÉ KŘOVISKO nebo SKRZ PICHLAVÉ SOUŠKY nebo SUCHÉ JEHLIČÍ SE SYPALO. Kdybych napsala: Místo bylo plné suchého jehličí, byla by ta věta zbytečně načervenalá a nehodila by se mi tam." 56

Jiný př́iklad, který Daisy Mrázková uvádí, je zobrazení klidného, stinného zákoutí v chládku blízko u vody. Opět analogicky příkladu suchého lesa umělkyně vyjmenovává písmena, z nichž se mají slova popisující prostředí skládat, a opět podává příklady nejvhodnějších slov. ${ }^{57}$

Nejsnazším vyjádřením viděných obrazů by pro Daisy Mrázkovou bylo pouhé nahromadění písmen či slabik vyjadřujících barvy, ale pro čtenáře by byl text naprosto nesrozumitelný. ${ }^{58}$ Tato písmena a slabiky je tedy nutné použít v dostatečném množství v textu, ${ }^{59}$ který se tak stává čtenáři srozumitelný a zároveň pro Daisy Mrázkovou neztrácí svou jedinečnou barevnost.

Při pokusu o potvrzení barevného vidění textu rozborem ohraničeného úseku textu z autorských knih Daisy Mrázkové se objevuje několik komplikací, a sice:

- chybějící propojení barvy u písmen $\mathrm{D}$ a Q, prakticky zejména písmena $\mathrm{D}$, protože písmeno Q se v českém jazyce vyskytuje naprosto výjimečně pouze u cizích slov

- přesné ohraničení textu zobrazeného na ilustraci

- doplnění synesteticky nepropojených barev či odstínů s konkrétním písmenem a jejich slovní popis v textu.

Přesto bych na několika vybraných ukázkách z autorských knih Daisy Mrázkové chtěla stvrdit či vyvrátit jednoznačnou synestetickou propojenost textu a doprovodné ilustrace.

$53 \mathrm{Viz}$ (pozn. 47), nepag.

${ }^{54}$ Ibidem, nepag.

55 Ibidem, nepag.

56 Ibidem, nepag.

57 Ibidem, nepag.

58 Ibidem, nepag.

59 Ibidem, nepag. 


\section{Synestetická propojenost textu a ilustrace u Daisy Mrázkové}

Originální barevnost ilustrací Daisy Mrázkové mě při objevu jejího synestetického vnímání specifických barev u jednotlivých písmen abecedy přivedla $\mathrm{k}$ myšlence experimentálního potvrzení této závislosti.

Pokusila jsem se v autorských knihách Daisy Mrázkové nalézt několik jasně ohraničených částí textu, u nichž bylo možné jejich přiřazení ke konkrétní ilustraci.

Každé jednotlivé písmeno z těchto vymezených textů jsem podle jeho barevného vnímání Daisy Mrázkovou převedla do barevné plošky čtverečku a podle jejich počtu je seskupila $\mathrm{k}$ sobě, aby vytvořily různě velké barevné plochy, které jsem srovnala s barevností ilustrací.

U některých autorských knih, jako je Byla jedna moucha či pozdějších Bilderbuchů, nebylo možné přiřadit konkrétní ilustraci jasně ohraničený text, a to bud’ $\mathrm{z}$ toho důvodu, že text vázající se k ilustraci byl př́liš krátký, anebo, a to častěji, nezobrazovala ilustrace jasně započatý a ukončený děj v textu.

První vybranou ilustrací byla ilustrace z autorské knížky Neplač, muchomůrko ze strany 19. K této ilustraci [obr. 2] jsem přiřadila následující část textu:

„Uprostřed jednoho kruhu byla pěkná pavučina mezi dvèma stébly. Kateřina si k ní sedla a dívala se. Na pavučině stála zrnka rosy, duhová barva se v nich mènila. Díváš se zleva, rosa je rưžová. Díváš se zprava, rosa je zelená. Díváš se zprostředka, a celá pavučina je fialová.

Kateřina pohybovala hlavou sem a tam, až se jí copánky po zádech házely. Jak je ta pavučina krásná!"60

První převod barevnosti písmen textu do plochy a jeho porovnání s barevností vlastní ilustrace $\mathrm{v}$ knize nebyl přesvědčivý. Pokusila jsem se barvy rozprostřené do plochy propojit, a sice šedou barvu se světle a tmavě zelenou, a to bez úpravy velikosti plochy, kterou po převodu z písmen vyplnily, a také jsem zintenzivnila světle modrou barvu zredukováním plochy na polovinu. Po těchto dvou následných úpravách si barevnost původní ilustrace a písmen převedených do barevné plochy vzájemně dobře odpovídá.

Velká plocha šedozelené trávy v lese je doplněna výraznou červenou a hnědou u pozadí kolem postavy Kateřinky a dále akcenty žluté, modré a červené barvy v detailech ilustrace.

Druhou vybranou ilustrací je ilustrace z autorské knihy Chlapeček a dálka, která zasahuje na strany 19 a 20 [obr. 3] a jíz jsem přiřadila tuto část textu:

„Na mezi seděl malír a maloval. Chlapeček se u něho zastavil a díval se. (Chlapečkové se vždycky dívají na malíře. Malír je jedna z nejlepších věcí, na kterou se chlapeček může dívat. U každého malíre stojí vždycky alespoň jeden chlapeček.)

Maliŕ neříkal nic. (Malíri nikdy nic neříkají. A to proto, že toho vědí moc!)

- Jste užitečný, pane?

- Kdepák!

- Ale ten obraz, je aspoň ten obraz užitečný?

- Vưbec ne, řkl malír a malounko se usmíval.

- Tak proč to děláte?

60 Daisy Mrázková, Neplač, muchomůrko, Praha 1965, s. 19. 
- Jen tak.

- Aha, ř kl chlapeček a začal štastně poskakovat.

- Já budu taky malír!"61

U této ilustrace je barevnost převedených písmen barevnosti ilustrace velice blízká. Vyskytují se tu i barvy použité na ilustraci v malých ploškách, jako je fialová barva čepice postavy vlevo, červená barva jejího svetru či oranžová na rolákovém svetru chlapečka, ve větších plochách pak různé odstíny zelené, modrá, hnědá nebo cihlová a červená.

Třetí vybranou ilustrací je celostránková ilustrace z autorské knihy Mưj medvěd Flóra. Stránky nejsou paginovány, zvolená ilustrace zobrazuje medvídka Flóru sedícího na otevřeném zeměpisném atlase. [obr. 4] Text doprovázející ilustrace je následující:

„Nejvíc se zajímá o zeměpis. Má atlas.

Neni to na ni trochu velké?

Ona si sedne doprostřed. Ona si poradí.

Které mapy má nejradši? Kavkaz,

Kanadu, kde jsou medvědi... Polární

medvědi ji nezajímají? Polární ani ne."62

V této knize je téměř na všech ilustracích zobrazen medvěd Flóra oblečený do růžových šatů po panence a na hlavě má červenobílou čepičku. Pro účely barevné analýzy písmen je tento $\mathrm{v}$ podstatě povinný kostým vyloučen. Ostatní barvy písmen abecedy převedených do barevné plochy odpovídají barvám ilustrace s převládající zelenošedou a hnědočervenou pozadí a modrým oceánům, hnědým pohořím a zeleným nížinám knižního atlasu s šedými a béžovými okraji.

Obecně lze u této analýzy písmen převedených do barevné plochy podle klíče synestetického vidění Daisy Mrázkové a jejich shod s ilustracemi v jejích autorských knihách uzavřít, že si vzájemně barevně odpovídají nebo ještě přesněji, že si neodporují.

Nejdůležitějšími barvami dle četnosti písmen jsou šedá, skleněná a tmavě zelená používané zejména na pozadí a tyto barvy jsou doplňovány výraznějšími barvami použitými na detaily ilustrací. Právě tyto méně četné barvy odlišují jednotlivé ilustrace a zdůrazňují důležité podrobnosti. V barevně analyzovaných ilustracích právě tyto detaily potvrdily, že si text s barvou ilustrace v autorských knihách Daisy Mrázkové skutečně odpovídají.

\section{Frekvenční výskyt písmen abecedy v českém jazyce v porovnání s texty Daisy Mrázkové}

Vzhledem k tomu, že tato analýza písmen textu autorských knih převedených do barevné plochy a její porovnání s vlastní ilustrací není zcela exaktní, ale závisí i na zvolených tónech jednotlivých barev či jejich kombinaci, rozhodla jsem se ještě porovnat frekvenční výskyt jednotlivých písmen české abecedy a jejich výskyt v úryvcích analyzovaných výše, abych zjistila, jestli Daisy Mrázková pomocí textu dokázala odlišnou frekvencí použití jednotlivých písmen abecedy ovlivnit barevnost ilustrací doprovázejících tento text.

61 Daisy Mrázková, Chlapeček a dálka, Praha 1969, s. 19-20.

62 Daisy Mrázková, Můj medvěd Flóra, Praha 2007, nepag. 
Frekvenční výskyt jednotlivých písmen české abecedy jsem převzala z Centra zpracování přirozeného jazyka (CZPJ), které vědecky působí na Fakultě informatiky Masarykovy univerzity v Brně. ${ }^{3}$ Písmena jsem zařadila do skupin, které jednotlivým barvám přiřazovala Daisy Mrázková, a vypočítala jsem jejich společnou frekvenci po těchto skupinách.

U všech tří textů, jejichž barevnost jsem porovnávala v experimentu výše, jsem vypočítala frekvenci výskytu a porovnala je s frekvenčním výskytem jednotlivých písmen české abecedy. Porovnání je dále uvedeno v Tabulce 3:

Tabulka 3: Porovnání frekvenčního výskytu písmen české abecedy s texty Daisy Mrázkové:

\begin{tabular}{|c|c|c|c|c|c|}
\hline \multirow[b]{2}{*}{ Skupiny písmen } & \multirow[b]{2}{*}{ Barva } & \multicolumn{4}{|c|}{ Frekvenční výskyt písmen abecedy (\%) } \\
\hline & & dle CZPJ & $\begin{array}{l}\text { Neplač, } \\
\text { Muchomůrko }\end{array}$ & $\begin{array}{l}\text { Chlapeček } \\
\text { a dálka }\end{array}$ & $\begin{array}{l}\text { Můj medvěd } \\
\text { Flóra }\end{array}$ \\
\hline a ági íju ůú & skleněná & 22,68 & 29,59 & 25,80 & 30,06 \\
\hline bf & fialová & 2,06 & 1,70 & 0,98 & 0,00 \\
\hline t t’e éè & zelená & 16,09 & 12,59 & 17,69 & 15,34 \\
\hline o óprřsšvxyý & šedá & 29,53 & 29,25 & 21,38 & 23,93 \\
\hline 1 & světle zelená & 4,10 & 4,42 & 6,63 & 2,45 \\
\hline$c \check{c}$ & žlutobílá/bílá & 2,62 & 2,04 & 3,93 & 0,61 \\
\hline$n n$ ň & oranžová & 6,75 & 5,44 & 5,65 & 9,20 \\
\hline $\mathrm{m}$ & červená & 3,26 & 1,70 & 3,44 & 4,91 \\
\hline h & cihlová & 1,30 & 2,04 & 0,98 & 0,00 \\
\hline $\mathrm{k}$ & hnědá & 3,75 & 3,40 & 5,41 & 3,68 \\
\hline $\mathrm{w}$ & vodová & 0,07 & 0,00 & 0,00 & 0,00 \\
\hline$z z ̌ z$ & rezavá & 3,15 & 3,40 & 3,19 & 2,45 \\
\hline ch & šedo/cihlová & 1,01 & 0,68 & 1,47 & 0,61 \\
\hline d d & - & 3,63 & 3,74 & 3,44 & 6,75 \\
\hline q & - & 0,01 & 0,00 & 0,00 & 0,00 \\
\hline celkem & & 100,00 & 100,00 & 100,00 & 100,00 \\
\hline 3 nejčetnější barvy & & 68,3 & 71,43 & 64,86 & 69,33 \\
\hline
\end{tabular}

Už pouhé seskupení písmen podle barev, které vnímá Daisy Mrázková, ukazuje zajímavý závěr. Šedá, zelená a skleněná barva reprezentují celkem $59 \%$ všech písmen abecedy a jsou v nich zahrnuty všechny samohlásky, ale jejich frekvenční výskyt je ještě zásadnější, protože představují $68 \%$ z celku. Při porovnání s ilustracemi Daisy Mrázkové není u této skupiny tří nejfrekventovanějších skupin a zprostředkovaně barev zásadní odchylka, ale porovnáme-li si každou jednotlivou skupinu z těchto tři u ilustrací Daisy Mrázkové se statistikou Centra zpracování přirozeného jazyka, je evidentní, že Daisy Mrázková upřednostňuje skupinu písmen představující pro ni skleněnou barvu před skupinou barvy šedé,

${ }^{63}$ https://nlp.fi.muni.cz/web3/cs/FrekvencePismenBigramu, vyhledáno 1. 6. 2017. 
tedy skupinou s významnějším podílem samohlásek než souhlásek. Největší podíl této skupiny se objevuje u autorské knihy Můj medvěd Flóra a souvisí s její podobou Bilderbuchu, v němž jsou používána kratší slova, u nichž se dá oprávněně předpokládat, že obsahují velký podíl samohlásek, aby se dětem ulehčilo jejich první čtení či pamětové učení, pro něž by bylo hromadění souhlásek obtížnější.

Další závěr, který lze z tohoto rozboru frekvenčního výskytu písmen vyvodit, platí pro užití písmen z ostatních, menších písmenkových skupin. Frekvenční výskyt písmen abecedy dle Centra přirozeného jazyka se individuálně liší u jednotlivých zvolených ilustrací z autorských knih, a to podle vnitřní potřeby Daisy Mrázkové zdůraznit vybrané detaily těchto ilustrací. K podobnému závěru jsem došla již v předchozí kapitole při prostém převodu barev písmen do obrazové plochy ještě bez rozboru frekvenčního výskytu písmen.

Přestože mnou vybraný vzorek ilustrací není statisticky reprezentativní, podle mého názoru ukazuje barevnou provázanost textu s ilustracemi v autorských knihách Daisy Mrázkové. Tuto závislost by při výběru většího počtu ilustrací a technicky progresivnějším způsobem převodu písmen do barevné plochy bylo jistě možné dopracovat do vědecky platných závěrů a přispět tak do stále se rozvíjejícího poznání specifik synestetického vnímání.

\section{Synestézie ve světovém výtvarném umění}

Fenomén synestézie je předmětem vědeckého zkoumání až v několika posledních desítkách let, ale popsán byl již na konci 19. století a u některých významných výtvarných umělců či hudebních skladatelů byla synestézie prokazatelně doložena. Mezi ně patří mimo jiné Vincent van Gogh a také Vasilij Kandinskij, jehož vlastní svědectví o prožitcích spojených se synestézií a vlastní tvorbou jím byly sepsány. ${ }^{64}$ Synestetické vnímání bylo připsáno také významným literárním umělcům, jako byl Vladimír Nabokov, který stejně jako Vasilij Kandinskij zanechal svědectví o vlastní synestézii ve své autobiografii, ${ }^{65}$ dále také Virginii Woolfové, Jamesi Joyceovi nebo Williamu Faulknerovi. ${ }^{66}$

Výtvarní umělci popisují poměrně často barevný či tvarový prožitek hudby - je tomu tak u Vasilije Kandinského či Pieta Modriana. U toho se však nejedná o barevnou synestézii, přestože zážitek z poslechu hudby zobrazoval v některých svých dílech. Hudba, zejména hudba jazzová, se mu nezobrazovala barvou, nýbrž rastrem linií a plošných geometrických obrazců (Kompozice se šedivými liniemi, 1918 či Vitězství Boogie-Woogie, 1942-1944). ${ }^{67}$ Piet Modrian již ve svých ranějších pracích promýšlel zobrazení pohybu, ale nedokázal jej zachytit jinak než statickou kompozicí, až podle jeho vlastních slov zjistil, že mu chybí rytmus, který pro něj přinesla právě jazzová hudba. ${ }^{68}$

O propojení barev a hudby (tónu) se pomocí různých experimentů pokoušeli již takoví filozofové ve starém Řecku, jakými byli Pýthagorás či Aristotelés. ${ }^{69}$ První vědecký

\footnotetext{
64 Viz Van Campen (pozn. 28), s. 56.

65 Vladimir Nabokov, Promluv, paměti, Praha 1998, s. 32-33.

66 Viz Van Campen (pozn. 28), s. 92.

67 Ibidem, s. 58.

68 Ibidem, s. 58.

69 Ibidem, s. 45.
} 
experiment, který měl dokázat závislost tónu a barvy, však byl proveden v Praze na dvoře císaře Rudolfa II. na konci 16. století malířem Arcimboldem, ${ }^{70} \mathrm{v}$ té době ale ještě fenomén synestézie nebyl popsán. $\mathrm{V}$ dalších stoletích se různí vědci či hudební skladatelé pokoušeli a dodnes pokoušejí o nalezení jednoznačných vazeb mezi barvami a hudbou s použitím rozličných teorií a pokusů s hudebními nástroji a technickými zařízeními. Jak již bylo řečeno, až v 19. století byl poprvé podrobněji identifikován a analyzován fenomén synestézie, který ale není vázán pouze na propojení hudby a barev, ale i mnoha dalších vjemů a jejich vzájemných kombinací.

První synestetické experimenty propojující malíre, hudební skladatele, tanečníky a herce, které měly vést $\mathrm{k}$ současnému prožití uměleckého díla všemi smysly, prováděla výtvarná skupina Blaue Reiter, založená v roce 1911. ${ }^{71}$ Sám Vasilij Kandinskij také napsal čtyři barevně-hudební dramata, například Žlutý zvuk $k^{72}$ (1909), jehož premiéra byla provedena až v sedmdesátých letech 20. století. Kandinskij se pokoušel spojit živě provedenou hudbu s vystoupením herců, zpěváků a tanečníků a proměnou nasvícení scény barevnými světly ${ }^{73}$ a obdobná propojení všech lidských vjemů doporučoval k experimentům svým studentům ve škole Bauhausu. ${ }^{74}$

Kandinskij zdůrazňoval význam barev v životě člověka, a to nejen umělce, přisuzoval jim enormní sílu, která působí „na veškeré projevy celého lidského organismu“ ${ }^{75}$.Odmítal pouhou asociativní sílu barev, přisuzoval jim přímý vliv na lidskou duši, a to v podobenství, v němž je barva klávesou, lidské oko kladívkem vedoucím klávesy do nitra nástroje-klavíru, kterým je lidská duše, a umělec pohybem svých prstů po klávesách určuje působení uměleckého díla na lidskou duši. ${ }^{76}$ Tuto závislost nazýval principem vnitřní nutnosti. ${ }^{77}$

Tato funkční a jednoznačná závislost je tedy vyjádřením jistého vnitřního zákona, který nedovoluje odchylky. Barvy pro něj měly svůj přesný význam, o jehož přenos na diváka se ve svých dílech, at už malírských či divadelních, umělec snažil. Kandinskij však svou teorii ještě obohacoval o druhý fenomén, kterým vedle barvy je také forma, jež vyznění barvy dále ovlivňuje. ${ }^{78}$ Nádherným prŕkladem je tvar trojúhelníku, jemuž Kandinskij přisuzoval duchovní vůni, která se s použitím různých dalších tvarů přidaných k trojúhelníku či barev trojúhelník vyplňujících mění. ${ }^{79}$ Barvy, tvary a všechny výrazové prostředky mají být zcela svobodné, použité v souladu s vnitřní nutností. ${ }^{80}$ Do jaké míry je tato vnitřní nutnost u Kandinského diktována specifickým neurologickým fenoménem, zvaným synestézie, který bezbřehou svobodu vlastně sám o sobě znemožňuje, dnes již nedokážeme rozhodnout.

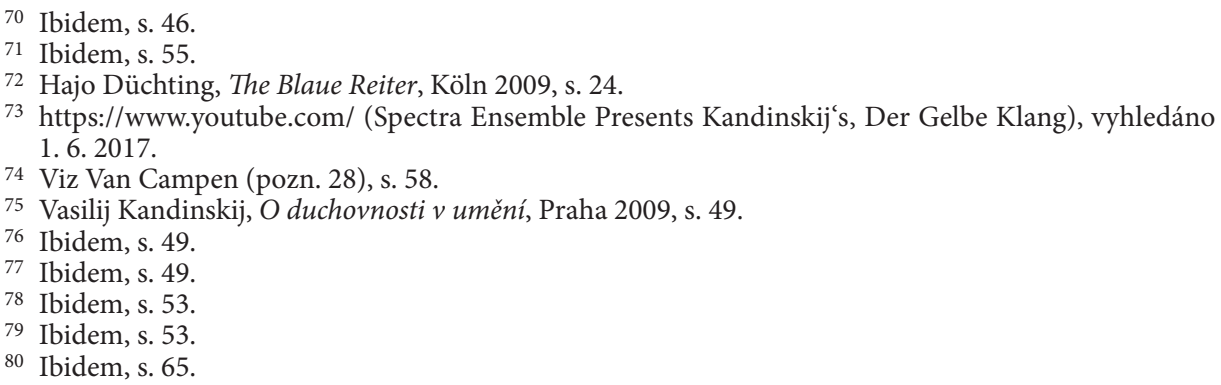


Kandinskij vypracoval vlastní teorii barev, založenou zcela na vlastních prožitcích a pozorováních. Neopíral se o žádné vědecké bádání či exaktní, ověřená fakta. ${ }^{81}$ Zatímco Daisy Mrázková zanechala pouze náznak svého vnitřního barevného života a jeho odrazu do vlastní výtvarné práce, Vasilij Kandinskij svou vnitřní teorii barev zdokumentoval do mnoha detailů týkajících se odstínů jednotlivých barev, jejich připodobnění k různým až extrémním životním situacím, v nichž se člověk může octnout, ale zabýval se i mísením barev, jejich intenzitou či umístěním v obraze. Naprosto typické pro Kandinského teorii barev je stálé přrirovnávání barevných prvků $\mathrm{k}$ hudbě, a to $\mathrm{k}$ tónům, zvukům, hudebním nástrojům. Jistě to byla i ozvěna tehdejších experimentů v oblasti hudby, které, pokud experimenty ve výtvarném umění nepředběhly, tedy s nimi alespoň zcela vyrovnaně držely krok. Pro Daisy Mrázkovou se barvy pojily s jednotlivými písmeny abecedy, pro Kandinského se barvy pojí kromě vnitřních pocitů se zvuky a tóny hudebních nástrojů. Umělec propojoval i obě umění ve své teorii, v níž mluvil mimo jiné o polyfonii barev či rozeznění barvy. ${ }^{82} \mathrm{U}$ moderního umění, a to jak maliřrského, tak hudebního, nacházel analogie ve své době, kdy se dřive nepřijatelná disharmonie začíná považovat za běžně přijatelnou ${ }^{83}$ protože umění je odrazem vnitřního života umělce bez ohledu na jeho přijatelnost vnějším světem, veřejností. Tento odraz vnitřního života v ilustracích i textech autorských knih Daisy Mrázkové je zcela jednoznačný, je primární, pohled čtenáře či diváka není při volbě barev a textu rozhodující.

Teorie barev Daisy Mrázkové není zdokumentovaná detailním teoretickým vysvětlením s praktickými príklady, ale je zdokumentována v jejích autorských knihách. Ty jsou však s odchodem Daisy Mrázkové již navždy pro kohokoli třetího pro převod její originální teorie barev do jazyka běžných smrtelníků nepřeložitelné. O zážitek z dvojjediné tvorby, umocněné fenoménem synestézie, se bohužel Daisy Mrázková kromě útlého katalogu k výstavě v Novém Městě na Moravě ${ }^{84}$ ve svých televizních, rozhlasových či novinářských rozhovorech nikdy nepodělila. Kandinskij je jedním z nemnoha výtvarných umělců, jehož svědectví o prožívání barevné synestézie je možné studovat a snažit se jeho prostřednictvím lépe pochopit specifika ilustrační tvorby Daisy Mrázkové, i přesto, že oba umělce dělí od sebe primárně čas, zkušenost, vzdělání, prostř̌edí, jejich naturel a druhotně rozsah jejich díla a jeho význam ve světových dějinách umění a jejich teorii.

Oba umělci mají společnou svou touhu po harmonii, která má být $\mathrm{v}$ jejich tvorbě právě prostřednictvím barvy vyjádřena. Pro Kandinského je cestou $\mathrm{k}$ dosažení harmonie plynoucí z vnitřní nutnosti zásadní kultivování citů. ${ }^{85}$ Pro autorské knihy Daisy Mrázkové je k dosažení harmonie mezi textem a ilustrací nutné jejich prolnutí. Daisy Mrázková o svých textech říká, že se v nich musí prolnout čtyři klíčové prvky: osobní pocit, vidění něčeho, vidění do něčeho a staré vědění ${ }^{86}$ Osobním pocitem je vlastní životní názor, vidění něčeho je pozorovaný vnější fyzický zážitek, vidění do něčeho představuje abstrahování a obecnější pohled na tento pozorovaný fyzický zážitek a starým věděním je

\footnotetext{
81 Ibidem, s. 69.

82 Ibidem, s. 87.

83 Ibidem, s. 86.

$84 \mathrm{Viz}$ (pozn. 47), nepag.

85 Viz Kandinskij (pozn. 75), s. 93.

${ }^{86} \mathrm{Viz}$ (pozn. 47), nepag.
} 
myšlena historická pamět člověka přenášená z generace na generaci a opět aplikovaná na pozorovaný fyzický zážitek. ${ }^{87} \mathrm{~K}$ textu se musí ještě připojit ilustrace a právě jejich propojením je dosaženo harmonie, cesta k ní však vyžaduje čekání a hledání. ${ }^{88}$ I pro Daisy Mrázkovou je cesta k harmonii závislá na citu pro propojení textu s obrazovým vyjádřením, nikoli na jejich mechanickém či asociativním propojení. Přestože Daisy Mrázková specificky nezmiňuje jako jeden ze záměrů ukrytých ve svých knihách Kandinským pojmenované kultivování citů, z jejích textů a ilustrací tento princip přímo dýchá. Když čtenář odloží dočtenou knihu z jejího pera, má pocit, že on sám i svět kolem něj je nějak lepší, správnější a spravedlivější a on je jeho samozřejmou součástí.

Jak Vasilij Kandinskij, tak i Daisy Mrázková, at už byla jejich teorie v detailu publikována, či nikoli, oba přiznávají působení vyšších sil, které zažívají při své tvorbě. Pro Kandinského je umělec poslušným služebníkem těchto vyšších sil, ale je zároveň zodpovědný za zušlechtění a rozvinutí vlastní duše, která má umocnit jeho přirozený talent. ${ }^{89}$ Daisy Mrázková zdůrazňuje trpělivost a otevřenost duše, jejichž propojením lze dosáhnout ideálního uměleckého vyjádření. ${ }^{90}$ Je synestézie touto vyšší silou? Diktují specifická neurologická propojení v mozku synestetickým umělcům ideál jejich tvorby? Pocitují synestetičtí umělci menší svobodu a volnost svého vyjádření?

Tyto otázky nejspíše nebude možné nikdy zodpovědět, protože lidské vnímání v oblasti umění je jedinečné a navíc u synestetiků nelze posoudit, jak by se jejich vnímání změnilo, pokud by synestetické propojení nefungovalo. Synestetické vnímání se simulovalo použitím drog, ale ani v těchto experimentech nelze činit pregnantní závěry, protože synestézie je vyvolána uměle a může mít odlišný průběh, trvání či intenzitu.

Jak Vasilij Kandinskij, tak i Daisy Mrázková zmiňují okamžik jakéhosi zjevení či prozření, který se dostaví při ideální konstelaci v jejich tvorbě a k němuž je vede cit $^{91}$ či krása, ${ }^{92}$ tedy zcela individuální kategorie vyplývající z jejich vnitřního života a podléhající tajemství, ${ }^{93}$ není exaktně pojmenovatelná. I tento pocit může být spojen se synestetickým vnímáním, s okamžikem, kdy všechny detaily vytvářeného díla precizně zaklapnou do vnitřní představy umělce.

Barevná teorie Vasilije Kandinského je zcela ojedinělá, protože individuální synestetické vnímání není založeno na žádné teorii, ale prostě se děje. Ani dva synestéti v jedné rodině nevnímají stejně, ani pokud se u nich projeví stejný typ synestézie. ${ }^{94}$ Je tedy asi oprávněné zvážit, do jaké míry je Kandinského teorie popisem jeho vlastního vnímání a jak se na ní podílejí soudobé vědecké a umělecké pokusy a atmosféra tehdejších převratných novinek oblasti umění a psychologie. Zásadním rozdílem mezi teorií vnímání umělce či vědce, kteří nejsou synestetiky, a teorií synestetika je možnost změny této teorie - umělec či vědec teorii může změnit na základě pokusů či pozorování, pro synestetika je teorie vnímání daná, měnit ji nelze. ${ }^{95}$

\footnotetext{
87 Ibidem, nepag.

8 Ibidem, nepag.

Viz Kandinskij (pozn. 75), s. 107.

$90 \mathrm{Viz}$ (pozn. 47), nepag.

91 Viz Kandinskij (pozn. 75), s. 107.

$92 \mathrm{Viz}$ (pozn. 47), nepag.

93 Viz Kandinskij (pozn. 75), s. 107.

94 Viz Van Campen (pozn. 28), s. 93.

95 Ibidem, s. 92.
} 
K zajímavému srovnání se u synestézie a jejího propojení s používáním nejen rodného, ale i cizích jazyků, které bylo zmíněno i u Daisy Mrázkové s ohledem na její bilinguálnost $\mathrm{v}$ češtině a angličtině, nabízí vnímání hlásek, specifických pro jednotlivé jazyky, jako různých druhů materiálů (např́klad dřevo nebo textil), které ve své autobiografii ${ }^{96}$ popsal Vladimír Nabokov. Projev synestézie u Nabokova, přestože se týká písmen, je zaměřen spíše na jejich zvuk, znění hlásek, nikoli tedy na barvu jako u Daisy Mrázkové. Nabokov vládl čtyřmi jazyky a i hlásky specifické jen pro některé z nich pro něj měly svou odpovídající podobu nějakého konkrétního fyzického materiálu ${ }^{97}$ nebo předmětu, jak popisuje ve svých memoárech. Přestože se specificky Nabokov o shodném znění hlásek v různých jazycích a jejich materiálové obdobě ve svém synestetickém vnímání nezmiňuje, lze předpokládat, že jejich materiálová podoba zůstala stejná. Analogicky pak pro Daisy Mrázkovou by barevná podoba písmen ve slovech v různých jazycích zůstávala nezměněná, tím spiše, že pro ni nebyla ani v českém popisu synestetického propojení písmen a barev důležitá interpunkce.

V procesech lidského vnímání a učení se lidé rozdělují do dvou základních skupin, a to podle základní logiky jejich přemýšlení a vnímání. První skupinu tvoří lidé, kteří vnímají v logických krocích postupně, v tomto případě mluvíme o postupném vnímání, druhou pak lidé, kteři vnímají najednou, u nich se jedná o vizuální vnímání, ${ }^{98}$ a právě mezi ně jsou v neurologickém pojetí řazeni synestetici, u nichž se experimentálně potvrzuje výrazně posílená kreativita ${ }^{99}$ ve srovnání lidmi upřednostňujícími postupné vnímání, ale dokonce i s lidmi, kteří vnímají vizuálně, ale nejsou synestetiky. Originalita a projev výtvarných umělců bezesporu závisí na jejich kreativitě a je-li umělec zároveň synestetikem, je jeho kreativita jeho prŕpadnou synestézií jistě umocněna. Síla a výpověd autorských knih Daisy Mrázkové je tedy rozhodně vnitřním souzněním textu a barev zásadně posílena.

Synestézií se dnes zabývají neurovědci na prestižních světových univerzitách a neurologie patř́ v posledních letech již mezi obecně přijímané metody moderní teorie dějin umění. Na univerzitě v San Diegu ve Spojených státech amerických se synestézií zabývá neuropsycholog Vilayanur Ramachandran, jehož bádání vstoupilo do povědomí teoretiků dějin umění, a to jak ve světě, tak v České republice.

Vědecké zkoumání synestézie, jak již bylo zmíněno, zatím spíše odkrývá hloubku a rozsah tohoto fenoménu, než aby vedlo $\mathrm{k}$ formulaci teorií a $\mathrm{z}$ nich vyplývajících závěrů. Obecně lze konstatovat, že synestézie je častěji identifikována u žen ${ }^{100}$ a umělců či kreativních osob, ${ }^{101}$ ale do jaké míry je toto rozložení v populaci exaktní a přesné, nelze určit, protože obě skupiny jsou obecně otevřenější v oblasti smyslového vnímání a jeho sdílení se svým okolím.

Další komplikací při zkoumání synestézie je množství jejích variant. Odborná literatura jich uvádí čtyřicet tři, ${ }^{102}$ ale vzhledem k individuálnímu vnímání jich může existovat ještě více. Nejčetnějšími podobami synestézie je propojení grafémů s barvou, časových

\footnotetext{
96 Viz Nabokov (pozn. 65), s. 32-33.

${ }^{97} \mathrm{Viz}$ Van Campen (pozn. 28), s. 94.

98 Ibidem, s. 85.

99 Ibidem, s. 87

100 Ibidem, s. 130.

${ }^{101}$ Ibidem, s. 132.

102 Ibidem, s. 131.
} 
jednotek s barvou, hudebních zvuků s barvou a nehudebních zvuků s barvou, ale existují i takové kombinace jako chut' a hmat nebo vůně a teplota. ${ }^{103}$

V České republice se fenoménu synestézie věnují literární vědci v Ústavu českého jazyka a teorie komunikace na Filozofické fakultě Univerzity Karlovy. ${ }^{104}$ Jejich odborné působení se dělí na publikační činnost a také na vlastní výzkum synestetického vnímání, jehož soustředěná analýza nebyla v České republice do té doby žádnou institucí či jednotlivci prováděna, přestože podle obecně přijímaného názoru, že v populaci žije přibližně $4,4 \%{ }^{105}$ synestetiků, by jich v naší zemi mělo být okolo $400000 .{ }^{106} \mathrm{~V}$ roce 2017 byl publikován výsledek jejich výzkumu, který prováděli ve spolupráci se třemi kanadskými univerzitami a Univerzitou ve Stanfordu, ve Spojených státech amerických. ${ }^{107}$ Výsledky výzkumu jsou publikovány odděleně pro data sesbíraná v České republice, ${ }^{108}$ takže se jejich závěry dají jednoduše použít při jakémkoli dalším bádání prováděném na našem území.

Jejich vědecké závěry vyplývající z výzkumu studentů na univerzitách v České republice a v Kanadě mají velice zajímavý vztah k Daisy Mrázkové, protože cílem jejich práce bylo potvrdit, zda výskyt synestézie závisí na zařazení rodného jazyka mezi jazyky transparentní (transparent) nebo jazyky nejasné (opaque), u nichž platí nejednoznačná pravopisná pravidla. ${ }^{109}$ Čeština byla zařazena mezi jazyky transparentní, angličtina pak mezi jazyky nejasné. ${ }^{110} \mathrm{Z}$ výzkumu mimo jiné vyplynulo, že u lidí, kteří se narodí do vícejazyčné rodiny a jsou přirozeně bilingvální, což byl četný př́ípad kanadských studentů, je synestézie mnohem méně častá než u lidí, kteří mají jeden rodný jazyk a dalším jazykům se učí až v průběhu svého života. ${ }^{111}$ Tento závěr by tedy u Daisy Mrázkové, bilingvální $\mathrm{v}$ češtině a angličtině, jistě nevedl k předpokladu její synestézie. Jak je však uvedeno v této vědecké studii, ${ }^{112}$ ale i v jiné odborné literatuře, ${ }^{113}$ která se zabývá synestézií a která je použita jako zdroj pro tuto práci, synestézie se častěji vyskytuje u osob umělecky zaměřených než v běžné populaci. Autoři však také uvažují i o opačné kauzalitě, a sice, že osoby umělecky zaměřené dokážou snáze svou synestézii identifikovat ${ }^{114}$ ve srovnání s osobami zaměřenými kupř́kladu technicky či exaktně.

A ještě jeden závěr studie mluví ve prospěch častějšího výskytu synestézie v našem prostředí a tedy specificky i u Daisy Mrázkové. Analýza výsledků tohoto průzkumu vedla ke konstatování, že u lidí s jedním rodným jazykem je synestézie daleko častější u jazyků nejasných než transparentních, ale s výjimkou jazyka českého, slovenského a ruského. ${ }^{115}$ Pokud se lidé, kteří nejsou od raného dětství bilingvální, učí dalšímu jazyku, musejí při tom hledat různé strategie osvojení tohoto dalšího jazyka v psaném, čteném i mluveném

\footnotetext{
103 Ibidem, s. 131.

104 http://ucjtk.ff.cuni.cz/veda-a-vyzkum/synestezie/, vyhledáno 1. 6. 2017.

105 Viz Watson-Chromý-Crawford-Eagleman-Enns-Akins (pozn. 34), s. 213.

106 Viz Chromý (pozn. 52), s. 382.

${ }^{107} \mathrm{Viz}$ Watson-Chromý-Crawford-Eagleman-Enns-Akins (pozn. 34), s. 212-231.

108 Ibidem, s. 212-231.

109 Ibidem, s. 213.

110 Ibidem, s. 213.

111 Ibidem, s. 222.

112 Ibidem, s. 223.

113 Viz Van Campen (pozn. 28), s. 132.

114 Viz Watson-Chromý-Crawford-Eagleman-Enns-Akins (pozn. 34), s. 223.

${ }^{115}$ Ibidem, s. 222.
} 
projevu, a tak se jim může snadněji odkrýt jejich synestetické vnímání. ${ }^{116}$ Autoři studia poukazují na jedno zdůvodnění této výjimky češtiny, slovenštiny a ruštiny mezi transparentními jazyky, zajímavé zejména pro tuto práci. Sovětské a bývalé sovětské satelitní národy mohou být se synestézií historicky lépe seznámeny, protože právě o některých světově uznávaných ruských či sovětských umělcích, jako byli Vasilij Kandinskij, Nikolaj Rimskij-Korsakov (1844-1908) nebo Alexandr Nikolajevič Skrjabin (1872-1915), se v souvislosti s jejich synestézii psalo už za jejich života. ${ }^{117} \mathrm{~K}$ tomuto zdůvodnění se však nepřikláním vzhledem k absenci odborných či populárních článků či publikací o synestézii v Čechách. Přestože se zmínky o synestézii v českém tisku vyskytují, jsou to s minimálními výjimkami, jako je článek Radkina Honzáka, ${ }^{118}$ krátké stati bez hlubšího rozboru. ${ }^{119}$

Na specifickou jazykovou a rodinnou situaci Daisy Mrázkové je asi nemožné výsledky této studie smysluplně aplikovat, protože její bilingvilita by ji řadila do skupiny, u které se synestézie projevuje méně často. Navíc jak angličtina jako jazyk nejasný, tak i čeština, řazená sice mezi jazyky transparentní, ale s jasnou tendencí k synestézii, by mohly synestetické vnímání Daisy Mrázkové naopak umocnit. Takovou specifickou variantu studie ale neřeší. Pokud bychom zvažovali autorčiny umělecké sklony projevující se již od mala, patřila by určitě mezi osoby k synestézii tendující. Každopádně ale tato vědecká analýza synestetického vnímání u kombinace česky a anglicky mluvícího vzorku populace, navíc se zohledněním bilingválního prostředí, má se synestézií Daisy Mrázkové jasné styčné body.

\section{Hledání analogií s vlivem synestezie Daisy Mrázkové v českém výtvarném prostředí}

V české výtvarné tvorbě 20. století na základě mého bádání není doloženo mnoho umělců či umělkyň, jejichž tvorbu by ovlivnila vrozená synestézie, což však jistě neznamená, že by se na českém území nevyskytovali. Při svém bádání v depozitáŕích diplomových prací českých univerzit jsem nalezla diplomovou práci zpracovávající dílo malíre Andreje Bělocvětova (1923-1997) ${ }^{120}$, jejíž autor jeho synestetické vnímání stručně popisuje $^{121}$.

Synestézie Andreje Bělocvětova propojovala hudbu a barvy. Měl od malička hudební nadání, které bohužel násilně potlačovala jeho matka. ${ }^{122}$ Autor diplomové práce považuje výtvarný projev Andreje Bělocvětova za jistou kompenzaci vlastního komponování či interpretování hudby. ${ }^{123} \mathrm{~V}$ prrípadě Andreje Bělocvětova mohla tedy synestézie fungovat dvojsměrně, tedy nejenže poslech či vlastní produkce hudby může vyvolávat barevné

\footnotetext{
116 Ibidem, s. 223.

117 Ibidem, s. 225.

118 Radkin Honzák, Chut' tónu, barva čísla; Synestézie, dar, o němž se moc nemluví, Vesmír LXXXVIII, 2009, č. 12, s. 780.

${ }^{119}$ Petr Třešňák, Jak chutná duha, Respekt 2016, č. 50, s. 69.

${ }^{120}$ Anděla Horová (ed.), Nová encyklopedie českého výtvarného umění, Praha 1995, s. 57.

121 Josef Šrejma, Andrej Bělocvětov - Theakston 1923-1997 (diplomová práce), Ústav pro dějiny umění FF UK, Praha 2009, s. 5.

122 Ibidem, s. 15.

123 Ibidem, s. 15.
} 
slyšení, ale i barvy mohou vyvolat hudební tóny. Kompenzací bych však jeho malování či kreslení nenazvala, protože $\mathrm{v}$ případě synestézie se jedná o spojenou, neoddělitelnou reakci na jeden podnět. Podle vlastních slov Andreje Bělocvětova má být obraz slyšet, měl by být vnímán všemi smysly a člověk by se skrz něj měl dotknout tajemství světa. ${ }^{124}$

Schopnost synestetického vnímání vzniká podle autora diplomové práce na základě různých zážitků v dětství, ${ }^{125}$ což neodpovídá vědeckým teoriím zabývajícím se problematikou synestézie, diskutovaným výše. Dětské zážitky mohou být klíčové pro identifikaci synestézii, nikoli však pro její vznik.

Autor některé své závěry zřejmě učinil na základě osobního rozhovoru s Andrejem Bělocvětovem. Neuvádí k nim však žádné zdroje, což znemožňuje si skutečnosti ověřit a dobrat se s jejich pomocí specifik synestetického projevu Andreje Bělocvětova. Lze tedy předpokládat, že se podle uvedených skutečností u Andreje Bělocvětova o synestetické vnímání barev a hudby opravdu jednalo, ale pro jednoznačné potvrzení by bylo nutné prověřit zdroje informací publikovaných v diplomové práci zabývající se jeho dílem a životem.

$\mathrm{V}$ dílech některých dalších českých výtvarných umělkyň a umělců jsem nalezla individuálně odlišná specifika jejich tvorby, na která bych v souvislosti se synestézií Daisy Mrázkové ráda upozornila. Jedná se o vybrané části výtvarného díla Věry Novákové $\left({ }^{*} 1928\right)^{126}$, Olgy Karlíkové $(1923-2004)^{127}$, Květy Pacovské $(1928)^{128}$ a Milana Grygara (1926). ${ }^{129}$

Věra Nováková používá ve dvou etapách svého výtvarného života v obrazech zakomponovaná písmena abecedy jako součást tvaru zobrazovaného předmětu či postavy, v jejímž názvu či jméně se písmeno objevuje v důležité pozici (na začátku slova, vprostřed krátkého slova či je ve slovu použito opakovaně), a spojuje tak význam slova s jeho tvarem.

Z jejího díla bych v souvislosti se specifiky synestézie popisovanými v tvorbě Daisy Mrázkové chtěla dále vyzdvihnout dvě etapy zaměřené na práci s písmem, k níž ji dovedly dvě experimentální skici z roku $1961^{130}$ a zejména pak spolupráce s Pavlem Brázdou na ilustracích ke knize Josefa Hiršala a Bohumily Grögerové Co se slovy všechno poví131. Způsob použití písmen v malířské tvorbě Věry Novákové se však od lettristických hrátek pro děti, představených v této knize, diametrálně odlišuje; lettrismus byl pro ni jen iniciačním impulsem. Věra Nováková použivá písmo ve svých obrazech vlastně už od padesátých let ve formě citací, ${ }^{132}$ ale pro porovnání s tvorbou Daisy Mrázkové je významné období let šedesátých a druhá vlna práce $\mathrm{s}$ písmem $\mathrm{v}$ letech devadesátých, $\mathrm{v}$ nichž jsou písmena abecedy promítnuta na plátna originálním způsobem, nikoli jako jejich pouhý textový doprovod.

\footnotetext{
124 Ibidem, s. 15.

125 Ibidem, s. 15.

${ }^{126}$ Richard Drury, Malovala jsem to, co jsem žila, in: Pavel Brázda - Richard Drury - Pavla Pečinková, Vèra Nováková, Praha 2010, s. 10.

127 Viz Hlaváčková (pozn. 26), s. 126, s. 129.

128 Viz Horová (pozn. 120), s. 595.

${ }^{129}$ Ibidem, s. 233 .

130 Pavla Pečinková, Na cestách bez ukazatele, in: Pavel Brázda - Richard Drury - Pavla Pečinková, Věra Nováková, Praha 2010, s. 36.

${ }^{131}$ Josef Hiršal - Bohumila Grögerová, Co se slovy všechno poví, Praha 1963.

132 Viz Pečinková (pozn. 130), s. 34.
} 
Věra Nováková používá tvar písmen abecedy přímo pro zobrazení postav či předmětů ve svých obrazech, maximální počet písmen zobrazených v jednom obraze jsou tř̀ a použitá písmena $v$ jednotlivých obrazech nevyčerpávají celou abecedu, není používána diakritika. Nejčastěji jsou používána písmena $\mathrm{S}, \mathrm{A}, \mathrm{V}, \mathrm{M}, \mathrm{K}, \mathrm{O}$.

Použití písmen v obrazech Věry Novákové by se dalo snadno vysvětlit pomocí asociace písmen a jejich významu, ale malířka sama toto primitivní řešení odmítá. Podobně jako Daisy Mrázková nedokáže identifikovat prvotní impuls - je primární slovo nebo obraz či vnitřní představa? „Slova se s představou obrazu nějak postupně spojují, jako když vzniká ... zárodek. Není to rozhodně věc vyspekulovaná, předem daná. (...) Narůstá [to] a prorůstá. Prorůstáním smyslu a tvaru se zabývám dlouho, propojením slova s tím vizuálním." ${ }^{133}$ Jednoduchou asociaci, hru s náhodně zvolenými významy slov spojených vybraným písmenem, lze tedy u Věry Novákové vyloučit. Synestézii však nejspíše také, protože ta se většinou projevuje současným vnímáním jedné skutečnosti více smysly a okamžitým spojením obou či dokonce více počitků, čemuž postupné a pracné propojení smyslu a tvaru u Věry Novákové neodpovídá. V ilustracích či obrazech Daisy Mrázkové nelze nalézt projev synestézie jednoduchým pozorováním, analýza barevnosti ilustrací a jejich souvislost $\mathrm{s}$ textem $\mathrm{v}$ jejích autorských knihách, jak jsem ukázala v předešlém textu, je pracná a zároveň také není zcela jednoznačná.

V písmenkových obrazech ${ }^{134}$ Věry Novákové lze použitá písmena identifikovat v zobrazených předmětech, postavách či krajině pomocí jejich tvarů bez jakýchkoli vážnějších problémů na první pohled. Sama Věra Nováková svou vlastní metodu použití písmen vymezuje v porovnání s lettrismem, v němž použitá písmena až ztrácejí svůj smysl,135 takto: „Jaký mohou mít smysl nejen slova, ale i písmena? Tím pro mne obživla, dostala svou vlastní řeč, vlastní život. Izolovala jsem je od slov a kupodivu se vrátila do ještě výraznější výmluvnosti. “136 Nejedná se u ní tedy o vnímání písmen souběžně alespoň dvěma smysly, tedy synestézii, ale spíše o hledání skrytého individuálního a individualizovaného smyslu každého písmena a jeho dekódování do výtvarné podoby.

Zcela svébytným výtvarným počinem Věry Novákové je experimentování s tvary písmen, jejichž geometrická výrazovost a osobitost se přímo odrážejí ve slovech a připomínají obrázkové písmo, jako by „slova byla př́mo srostlá se svým obrazovým tvarem“.137 Písmena se ve slovech vyskytují jednou či vícekrát, nejčastěji na začátku slova. Ani Věra Nováková, stejně jako Daisy Mrázková, nepracuje s interpunkcí a její výtvarná metoda není vázána pouze na češtinu. Je tedy univerzálnější, použitelná v různých jazycích, jak lze snadno demonstrovat na příkladu písmena A, u něhož jsou Věrou Novákovou uváděna slova nejčastěji latinského původu.

Synestetické vnímání skutečnosti a její promítnutí do výtvarného díla Věry Novákové bylo tedy analýzou velice originálního oddílu její tvorby využívající práci s písmem a výraznou škálou barev vyloučeno a možná analogie s autorskými knihami Daisy Mrázkové se nepotvrdila.

\footnotetext{
133 Petr Placák, Smích slepé směrovky chilli suche sich selbst, Babylon, březen 2010, č. 7,

134 Viz Pečinková (pozn. 130), s. 34.

135 Ibidem, s. 36.

136 Ibidem, s. 36.

${ }^{137}$ Pavel Brázda, Průvodce obrazy, in: Pavel Brázda - Richard Drury - Pavla Pečinková, Věra Nováková, Praha 2010, s. 136.
} 
Výtvarné dílo Olgy Karlíkové má neobvyklý rozsah od kresby, malby a frotáží k návrhům na tapisérie, předložky, koberce, dekorativní textilie, vzory látek a šatů. ${ }^{138}$ Část jejího především kresebného, ale i malířského díla je však zcela originální a přiměla mě ji zařadit do skupiny umělců, u nichž by bylo logické očekávat synestetické vnímání. Olga Karlíková naslouchala v přírodě zpěvu ptáků či žabím hlasům a prrímo in situ převáděla jejich zpěv do kresby, a tedy kombinovala tak vjem sluchový a zrakový. Jeho záznam prováděla nejčastěji v prrírodě, a to především brzy ráno a vpodvečer, ale ptačí zpěv si i zaznamenávala na nahrávacím zařízení a mohla jej převést do grafické podoby později.

Ze zvukového záznamu naslouchala i velrybímu zpěvu a také ten kresebně zaznamenávala. Prvotním záznamem hlasu ptáků, žab i velryb byl záznam kresebný, dochovaly se však též záznamy malířské. V těchto grafických záznamech zvuků dominuje černá barva tužky, tuhy nebo tuše na bílém svitku či archu papíru, ale vybrané záznamy jsou pojednány i barevně, zejména $\mathrm{v}$ podobě malby, ale i kresby barevnými fixami zaznamenávající vícehlasé ptačí projevy.

Olga Karlíková hledala zdroje své výtvarné inspirace především v př́írodě, která pro ni byla jistotou „nepodléhající lidským slabostem“. ${ }^{139}$ Velmi brzy se jako zásadní podnět pro její tvorbu objevili ptáci, ovšem nikoli jejich zpěv, nýbrž podoba jejich těl či letu, ${ }^{140}$ odvěkému symbolu svobody. První kresby zaznamenávající ptačí zpěv „byly váhavé“, 141 ale Olga Karlíková si postupně vybudovala grafický rejstř́í znaků, který představoval její vnitřní vidění podoby jednotlivých ptačích hlasů a jejich specifičnost. ${ }^{142}$ Velmi zjednodušeně by se dalo toto vnímání popsat jako jistá forma abecedy, kdy každému ptačímu zvuku je přiřazena jeho grafická podoba různě orientované, lomené, kroucené i přerušované linie odlišné délky.

Olga Karlíková začínala menšími formáty záznamů ptačího zpěvu, ale jak postupně systematickým zaznamenáváním získávala jistotu grafické podoby zpěvu jednotlivých ptačích druhů, začal se tento formát zvětšovat až do podoby velkých svitků, na nichž v posledním roce života zaznamenávala i další projevy př́rody, jakými byla třeba blížící se bouřka nebo cit ovlivňující zpěv ptáků. ${ }^{143}$ Extrémním byl jistě celodenní záznam ptačího koncertu z roku $1984 .{ }^{144}$

Dlouhé minuty i hodiny dokázala Olga Karlíková věnovat pozorování letu a kroužení ptáků, ${ }^{145}$ ale pro své výtvarné vyjádření si zvolila jejich zpěv, ten nejméně hmotný projev. V pojetí Olgy Karlíkové však při převádění zvuku do grafické podoby nešlo čistě o záznam hmotného světa, ale o vnitřní pochopení skrytého vyššího přírodního řádu, ${ }^{146}$ o jeho zaznamenání a zpř́stupnění.

Olga Karlíková si byla podle tvrzení Miroslavy Hlaváčkové, založených nejspíše na osobních rozhovorech, svého synestetického vnímání vědoma, „zpěv [ptáků] se jí promítl

\footnotetext{
${ }^{138}$ Viz Hlaváčková (pozn. 26), s. 127.

139 Ibidem, s. 24.

140 Ibidem, s. 127.

${ }^{141}$ Ibidem, s. 17.

142 Ibidem, s. 17.

143 Ibidem, s. 17.

144 Ibidem, s. 39.

145 Ibidem, s. 26.

146 Ibidem, s. 27.
} 
na sítnici jako grafický záznam“. ${ }^{147}$ Postupně se synestetickým vjemům zažívaným při poslechu zpěvu ptáků začala věnovat naprosto systematicky, studovala odbornou literaturu, korespondovala s hudebními vědci, zaznamenávala zpěv ptáků a krok za krokem sestavovala grafický ptačí zpěvník, který převáděl charakteristický zpěv různých druhů ptáků do výtvarné podoby. ${ }^{148}$

Záznamy žabího zpěvu či kuňkání se od záznamů zpěvu ptáků výtvarně odlišují. Jednotlivé zvuky jsou řazeny do neuspořádaných řádek, nejsou to linie, ale krátké tahy plochým štětcem, skvrny, a vzájemně se přesahují a zaplňují celé archy papíru. Olga Karlíková pro záznam žabích zvuků používá často barvy, a to různé odstíny zelené až zelenohnědé, symbolizující barvu žabích těl či okolní přírody, a modrou barvu vody a nebe. Barvy nezaplňují celou plochu, takže mezi nimi prostupuje i bílá barva podkladu.

Také záznam velrybího zpěvu je zcela originální a od výtvarné podoby ptačího zpěvu a žabích zvuků se zcela odlišuje. Záznam tvoří linie stoupající jako gejzír ze spodní části obrazu vzhůru a snad zobrazuje cestu zvuku z podmořských hloubek až nad hladinu.

Miroslava Hlaváčková ve svém textu uvedeném v monografii Olgy Karlíkové o jejím vnímání píše zcela jednoznačně jako o vnímání synestetickém. Teoreticky jej z pohledu neurologického neanalyzuje ani nevysvětluje, zaměřuje se na pojetí tohoto vnímání jako naprostého splynutí s př́rodou a její pochopení. Olga Karlíková je mezi české výtvarníky se synestetickým vnímáním zařazena naprosto oprávněně, její specifické vnímání převádělo zvuk do jednoznačné grafické podoby. Tato podoba synestézie je velmi ojedinělá, $\mathrm{v}$ přehledu kombinací spojených vjemů u synestetického vnímání není vůbec uvedena. ${ }^{149}$

Květa Pacovská v jednom ze svých nedávných rozhlasových rozhovorů ${ }^{150}$ mluví o významu barev pro svou tvorbu, a to zejména tvorbu ilustrační. V souvislosti se synestézií však zmiňuje své propojení vnímání barevnosti s jednotlivými dny v týdnu a uvádí, že ji v dětství překvapovalo, že tohle vidění nemá každý. ${ }^{151}$ Toto fyziologické propojení barev je typické pro syntetické vnímání. Květa Pacovská tedy s velkou pravděpodobností propojuje touto velmi pozoruhodnou vazbou barvy s dny v týdnu, které se ale v průběhu času mohou měnit, jednotlivé dny nemají celoživotně jednu barvu. Barva dne v týdnu se může měnit v závislosti na vnitřních pocitech i počasí či okolní situaci vzniklou v konkrétním dni.

Barvy jsou pro Květu Pacovskou klíčové nejen v její tvorbě, ale i v každodenním životě. Každé barvě přisuzuje určitou jasnou charakteristiku. Černou barvu považuje za královnu barev kvůli její hloubce, zelená je pro ni barvou životodárnou, jejími nejoblíbenějšími barvami jsou pak červená a modrá. ${ }^{152}$

Způsob barevného vnímání dnů v týdnu popisovaný Květou Pacovskou je typický pro synestetiky, přestože je propojení velice neobvyklé a v použité literatuře nepopsané. ${ }^{153}$

\footnotetext{
147 Ibidem, s. 36.

148 Ibidem, s. 36.

${ }^{149}$ Viz Van Campen (pozn. 28), s. 131.

150 https://wave.rozhlas.cz/kazdy-den-ma-svou-barvu-rika-ilustratorka-kveta-pacovska-8123016, vyhledáno 9. 12. 2019.

151 Ibidem.

152 Ibidem.

${ }^{153}$ Viz Van Campen (pozn. 28), s. 2.
} 
Zásadní přelom v tvorbě Milana Grygara znamená rok 1965, kdy objeví svůj vlastní princip akustických kreseb, ${ }^{154}$ který výtvarnou podobu kresby prováděné dřívkem současně snímá i akusticky - zaznamenává zvuky dřívka tvořícího kresbu. Dalším krokem $\mathrm{v}$ jeho výtvarných pokusech je zapojení mechanických předmětů do tvorby akustických kreseb. Mezi nejčastěji používané předměty, pro které bylo typické, že zanechávaly po namočení do barvy na papíre svým pohybem body, čáry nebo jiné stopy, patřila ozubená kolečka, šrouby, součástky z hodinového strojku nebo natahovací kovové hračky jako slepičky nebo žabky či rotující hračka vlček. ${ }^{155}$

V originálním experimentování mimo jakoukoli uměleckou skupinu pokračuje po celou svou výtvarnou kariéru. Po akustických kresbách vytvářel půdorysné partitury, hmatové kresby či lineární a prostorové partitury nebo velký cyklus Antifony. Tyto různé typy tvorby Milana Grygara mají jeden společný charakteristický prvek a tím je propojení kresby nebo malby se zvukem, jejichž spojením je zasažen prostor. Kresba a malba tak naplňují třetí rozměr.

Právě toto spojení dvou vjemů - zrakového a sluchového - mě vedlo k bližšímu zkoumání díla Milana Grygara v souvislosti se synestetickým vnímáním Daisy Mrázkové. Zřejmě nejblíže se možnému synestetickému vnímání nabízejí akustické kresby Milana Grygara, a to prvotní akustické kresby ještě bez zapojení mechanických předmětů, které vnášejí do akustických kreseb princip náhody zcela bez vlivu umělce, a tedy vylučují synestetické vnímání. Z rozhovorů ${ }^{156} \mathrm{~s}$ Milanem Grygarem ${ }^{157}$ se však synestetické vnímání nepotvrzuje, nejde o propojení dvou způsobů vnímání, ale o záznam dvou sice vzájemně podmíněných, souvisejících vjemů, ale nikoli neurologicky propojených. A také pozdějši zapojení mechanických předmětů do tvorby akustických kreseb popírá neoddělitelnost zvukového a zrakového vnímání. Navíc grafické podobě kresby neodpovídá žádný konkrétní zvuk, který by se jako u záznamů ptačích zpěvů Olgy Karlíkové dal sestavit do určité podoby zvukové abecedy. Synestetickému vnímání také odporuje fakt, že podle Milana Grygara může zvukový záznam fungovat samostatně, není nutné jeho propojení s původní kresbou.

V dokumentu televize Artyčok z roku 2016 je autory zmíněno synestetické vnímání u cyklu Antifon, ${ }^{158}$ v němž Milan Grygar pracuje s dvojicemi obrazů umístěnými vždy těsně vedle sebe. Tyto dvojice představující geometrické obrazce stejné barvy, ovšem $\mathrm{v}$ různé velikosti, které právě svými rozměry vytvářejí odlišně hloubku zobrazovaného a vnímaného prostoru. Vrací se v nich po mnoha letech od spojení kresby a zvuku ke spojení barvy a prostoru. Synestetické vnímání barvy a prostoru není ve známých či vědecky popsaných kombinacích vůbec uvedeno, ale totéž platilo i u specifického vnímání zvuku a kresby u záznamů ptačích a žabích zpěvů či zvuků velryb u Olgy Karlíkové. U Milana Grygara však proti synestetickému propojení barvy a prostoru mluví použití jedné barvy pro různě hluboký prostor, jeho rozměr tedy není spojen s konkrétní barvou.

\footnotetext{
154 Jean-Yves Bosseur, Milan Grygar a zvuk, in: Jiří Zemánek - Milan Grygar (eds), Milan Grygar, Obraz a zvuk, Image and Sound, Praha 1999, s. 14.

155 Ibidem, s. 15.

156 http://artycok.tv/28868/milan-grygar, vyhledáno 1. 6. 2017.

${ }^{157}$ Hana Larvová, Milan Grygar, Vizuální a akustické, The Visual and the Acoustic, Praha 2014.

158 http://artycok.tv/28868/milan-grygar, vyhledáno 1. 6. 2017.
} 
Jiné propojení, a to u fenoménu synestézie asi nejčastější, naznačuje sám Milan Grygar, a sice když připodobňuje barvu ke zvuku a zdůrazňuje jejich podobné vlastnosti transparentnost, chvějivost a tonalitu. ${ }^{159}$ Zároveň však poznamenává, že jde o analogii, nikoli tedy vnitřní podmíněnost, která by vznikala na základě neurologického propojení dvou vjemů plynoucích z jednoho externího podnětu.

Z této podrobnější analýzy díla Milana Grygara tedy nelze uvažovat o možnosti synestetického vnímání, kterému obecně známé propojení zvuku a obrazu či prostoru v jeho díle slibně napovídalo. Jeho světově originální dílo není ovlivněno neurologickým propojením vnímání, ale vlastní promyšlenou technickou a estetickou koncepcí.

\section{Závěr}

Daisy Mrázková po ilustrační tvorbě vždy velmi toužila, zakázky se však př́liš nehrnuly. Zlom přišel až téměř $v$ polovině šedesátých let, $k d y$ dostala možnost postupně vydávat své autorské knihy, v nichž figurovala jako ilustrátorka a spisovatelka. Tímto ojedinělým propojením došlo k naprostému prolnutí textu a obrazu, které bylo ještě umocněno synestetickým vnímáním písmen a barev.

Přestože nikdy nedokončila své výtvarné vzdělání, věnovala se především své rodině a malovala či kreslila jen ve chvilích volna, stala se v porovnání s mnoha spolužáky ateliéru Antonína Strnadela na pražské UMPRUM odbornou veřejností uznávanou a laickým publikem milovanou autorkou. I když její jméno nebývá uváděno na čelných místech v přehledech tvorby umělců druhé poloviny dvacátého století, její tvorba odrážela specifika doby, jak je prožívala se svými práteli zejména ze skupiny UB 12. Pokud zkoumáme výtvarnou tvorbu Daisy Mrázkové, a to jak volnou, tak ilustrační, je evidentní, že je zcela originální. Pramení $\mathrm{z}$ vnitřní potřeby umělkyně, jež pracuje sice s výtvarnými podněty získanými v průběhu svého života, ale nekopíruje, na žádného umělce či směr se přímo neodvolává. Její umění je niterné, jemné, pozitivní, neapeluje, ale pokud se mu člověk pokouší porozumět podrobným zkoumáním, pohlcuje ho svou opravdovostí.

V čem tedy spočívalo ono zvláštní kouzlo autorských knih Daisy Mrázkové? Odpověd' není jednoduchá.

Daisy Mrázková nebyla extrovertkou, žila již odmalička v určitém omezeném chráněném prostoru, nejprve dlouhá léta se svou anglickou maminkou a pak se svou rodinou, manželem Jiř́m, dcerou Veronikou a synem Cyrilem. Svou vášeň pro malování a četbu měla v sobě od útlého dětství, a mohla tak rozvíjet svou fantazii a bohatý vnitřní svět. Její inspirací k pozdější tvorbě autorských knih byly kvalitní české a anglické knihy a krátké učebnice, které ji nenápadně směřovaly $\mathrm{k}$ určité lakonické výstižnosti textu a poetickým originálním ilustracím. Barevnost jejích ilustrací v autorských knihách byla založena především na barevném vidění napsaného textu, ale i na vnímání neobvyklých barevných kombinací pozorovaných třeba při její jediné návštěvě Anglie.

Doba padesátých a šedesátých let nutila umělce, kteří neopustili svou vlastní uměleckou cestu ve prospěch socialistického realismu a nezačali sloužit komunistickému režimu, aby se stáhli do svých rodinných a prátelských kruhů a jen tam v tvorbě podle

${ }^{159}$ Ibidem. 
vlastního přesvědčení dále pokračovali. Daisy Mrázková byla jednou z nich. Její dílo bylo obdobně jako tvorba dalších jí blízkých umělkyň, jakými byla Věra Janoušková či Adriena Šimotová, více vázáno na její vlastní soukromou existenci, než tomu bylo u mužů. ${ }^{160}$ Do jejich tvorby pak vstupovaly určité autobiografické prvky, jakými v autorských knihách Daisy Mrázkové bylo zejména prostředí lesa, v němž se její hrdinové pohybovali, či příběh nálezu medvídka Flóry, kterého našel její syn Cyril.

V symbióze žili a tvořili vedle sebe s manželem Jiřím, který pracoval ve svém ateliéru, zatímco Daisy Mrázková přímo doma v nuselském bytě, který nebyl př́liš velký a Mrázkovi jej sdíleli s její maminkou. Až časem se jim podařilo byt rozšírit a používat jeho část jako ateliér a depozitár. I tyto skutečnosti vedly jistě Daisy Mrázkovou k introvertnímu zaměření její tvorby.

Vlastní práce umělců, kteří nemohli svobodně vystavovat, byly tedy konfrontovány pouze v úzkém okruhu spř́żněných osob. Jistě chybělo porovnání vývoje s jinými alternativními skupinami Československu nebo v zahraničí. Své dílo nemohli považovat za zdroj obživy, mohli se v něm ale projevit zcela svobodně. ${ }^{161}$

Ve svých autorských knihách klade umělkyně důraz na pozitivní přístup k životu, vyzdvihuje dobré vztahy v rodině a s přáteli, klade důraz na samostatnost a odvahu svých dětských i zvírecích hrdinů a ochotu postavit se nespravedlnosti a zlu.

Její ilustrace mají často abstrahující nádech, což v porovnání s československými ilustrátory a tvůrci autorských knih pro děti nebylo př́liš obvyklé, snad s výjimkou Stanislava Kolíbala, jehož ilustrace ke Stromu pohádek z celého světa ${ }^{162}$ v roce 1958 nebyly tehdejším režimem pozitivně přijaty, protože se zcela rozcházely s do té doby jasně podporovanou podobou výtvarných děl v duchu socialistického realismu. Právě abstraktní prvek a použití neobvyklých barev a jejich spojení s textem, který nedoříkává př́iběh do úplných detailů, podporuje představivost čtenáře a diváka a nechává mu prostor $\mathrm{k}$ vlastnímu dotvoření příběhu.

Daisy Mrázková, zřejmě silně inspirována anglickou literaturou pro děti a mládež a krátkými knížkami pro první čtení, používanými jako nedílná součást výuky anglického jazyka, užívá ve svých textech stručný a výstižný jazyk bez detailních popisů, díky němuž plyne svižně děj a zůstává již zmiňovaný prostor pro fantazii diváka.

Tento princip určitého spoluautorství čtenáře a diváka považuji v tvorbě Daisy Mrázkové za klíčový. A přesto se Daisy Mrázková nevzdává svého působení na čtenáře, stále směřuje k dobru, spravedlnosti, porozumění, lásce a přátelství a tím formuje a vychovává, aniž by prvoplánově nabádala či přikazovala. K tomuto účelu používá i postavy svých hlavních hrdinů, kterými bývají bud' samy děti, anebo zvířata, kterým propůjčuje dětské uvažování. Čtenář a divák se pak snadněji vžívá do př́íb̌hu, který se může s velkou pravděpodobností přihodit i jemu samotnému.

Synestetické vnímání Daisy Mrázkové nebylo v odborné literatuře dosud zpracováno a představuje zcela ojedinělý prvek, jehož vliv na podobu ilustrací v jejích autorských knihách jsem experimentálně zkoumala. Synestézie je ve světě předmětem zkoumání mnoha odborníků z rozličných vědeckých oborů a v posledních letech se do něj začali zapojovat i odborníci z České republiky. Synestetické vnímání bylo vlastní i některým významným

160 Jindřich Chalupecký, Nové umění v Čechách, Praha 1994, s. 112.

161 Ibidem, s. 159.

162 Jan Vladislav - Vladislav Stanovský, Strom pohádek z celého světa, Praha 1958. 
výtvarným umělcům a hudebníkům ve světě, a protože je vědecky doloženo, že přibližně 4 \% populace takto vnímají, pokusila jsem se nalézt i v českém prostředí výtvarné umělce, jejichž tvorba byla synestézií ovlivněna. Mezi ně lze zařadit Olgu Karlíkovou a Andreje Bělocvětova, u dalších se synestetické vnímání neprokázalo.

Tvorba Daisy Mrázkové, at’ už jsou jí ilustrace a autorské knihy, či volná tvorba, bohužel stále čeká na uměleckohistorické zpracování. Její jméno se na rozdíl od většiny přátel a kolegů ze skupiny UB 12 nevyskytuje ani ve dvou zásadních výstavních a badatelských projektech ${ }^{163}$ věnujících se umění po roce $1945^{164}$ či v přehledových uměleckohistorických pracích. ${ }^{165}$

Tento text rozebírá specifika synestetického vnímání při rozboru autorských knih Daisy Mrázkové. Snad přispěje k budoucímu odbornému zhodnocení celého výtvarného díla Daisy Mrázkové.

\section{SUMMARY}

\section{Synaesthesia in the author's books of Daisy Mrázková}

The paper analyses the author's books, in which the illustrations and text are created by the same author, the Czech artist Daisy Mrázková. Her twelve author books for children were published between the sixties and early eighties with one late exception published in 2009. Her books are famous for their specific atmosphere of the indefiniteness, open endness, positivity and a certain level of mystery. The heroes are the children or talking animals which help the reader to identify with the story. Mrázková's intention was not only to amuse but also to educate. Some of the author's books are intended for the reading in loud and the joint enjoyment of the children and the adults. The texts reflect the specific double-track.

The paper explains the family background, education and individual characteristics of the author and her children books inspiration. It briefly analyses the individual author's books.

The paper focuses on the specific gift of Daisy Mrázková - the synaesthesia. This is a special way of perception in which one external impulse impacts more than one human sense at the same moment and connects them in one reflection. The most usual combination is colour/letter, colour/digit, colour/tone. The synaesthesia is not an association, it is inborn. All newborns are synaesthets but the sense interconnections are gradually lost from the age of 6 months up to approx. 11 years.

Daisy Mrázková's synaesthesia connects the colour with the specific alphabet letters. The colours are the key for the text of the book. The colours of the individual scenes of the story in her imagination specify the letters for the words in which Mrázková tells her story.

In the experiment I wanted to confirm the connection between the text of Mrázková's author's books and her illustrations. Three examples of the text which could be directly associated with a specific book illustration were used for the analysis. The text was bro-

${ }^{163}$ Marie Klimešová, Roky ve dnech, Praha 2010.

${ }^{164}$ Marie Judlová (ed.), Ohniska znovuzrození, Praha 1994.

165 Viz Chalupecký (pozn. 160). 
ken into the individual letters and these were associated with the colours that Mrázková specified in writing. The resulting colours were compared to the book illustration.

Furthermore, a specific analysis of the frequency of occurence of the letters of Mrázková's text as compared to the general frequency of ocurrence of the letters of the Czech alphabet was performed. The result showed the specifics of Mrázková's language used in the author's books which confirmed the synaesthesia related modification to the general Czech language.

The paper also discusses the synaesthesia among the foreign artists including Vasilij Kandinskij, Piet Mondrian, Virginia Woolf, James Joyce or Vladimir Nabokov. The paper also focuses on several Czech artists of the second half of the twentieth century in the art of which the synaesthetic perception might be identified.

Although there are many matters which contribute to the originality of Daisy Mrázková's author's books like her introvert personality, love for nature, religion belief or various artistic and literary inspirations, the synaesthesia seems to be the crucial factor which brilliantly unifies the illustrations and the text.

\section{VÝBĚROVÁ BIBLIOGRAFIE}

Cretien Van Campen, The Hidden Sense, Synesthesia in Art and Science, Massachusetts 2010

Daisy Mrázková, katalog Horácké galerie, Nové Město na Moravě 2003, nepag.

Hajo Düchting, The Blaue Reiter, Köln 2009.

Richard Drury, Malovala jsem to, co jsem žila, in: Pavel Brázda - Richard Drury - Pavla Pečinková, Véra Nováková, Praha 2010.

Ivo Fencl, Daisy Mrázková - renesanční autorka knih pro děti, www.citarny.cz, 14. 9. 2014, nepag.

Miroslava Hlaváčková, Olga Karlíková, Louny 2001, nepag.

Radkin Honzák, Chut tónu, barva čísla; Synestézie, dar, o němž se moc nemluví, Vesmír LXXXVIII, 2009, č. 12, s. 780 .

https://wave.rozhlas.cz/kazdy-den-ma-svou-barvu-rika-ilustratorka-kveta-pacovska-8123016, vy-

hledáno 9. 12. 2019

https://nlp.fi.muni.cz/web3/cs/FrekvencePismenBigramu, vyhledáno 1. 6. 2017.

http://www.pribehrozhlasu.cz/odhaleni-89+1/slavne-porady/2804982, vyhledáno 1. 6. 2017.

http://www.slovnikceskeliteratury.cz/, vyhledáno 1. 6. 2017.

https://www.youtube.com/ (Spectra Ensemble Presents Kandinskij's ,Der Gelbe Klang), vyhledáno 1. 6. 2017.

http://ucjtk.ff.cuni.cz/veda-a-vyzkum/synestezie/, vyhledáno 1. 6. 2017.

Jindřich Chalupecký, Nové umění v Čechách, Praha 1994.

Jan Chromý, Synestézie a její lingvistické aspekty, Československá psychologie, č. 54, 2010, s. 386.

Marie Judlová (ed.), Ohniska znovuzrození, Praha 1994.

Vasilij Kandinskij, O duchovnosti v umění, Praha 2009.

Marie Klimešová, Roky ve dnech, Praha 2010.

Jaroslav Pažout (ed.), Každodenní život v Československu 1945/8-1989, Praha 2015.

Milena Slavická, UB 12 - studie, rozhovory, dokumenty, Praha 2006.

Blanka Stehlíková - Věra Vařeková - Ondřej J. Sekora, Ondřej Sekora - Práce všeho druhu, osobnost a dílo, Praha 2003.

Marcus R. Watson - Jan Chromý - Lyle Crawford - David M. Eagleman - James T. Enns - Kathleen A. Akins, The prevalence of synaesthesia depends on early language learning, Consciousness and Cognition, č. 4, 2017, s. 214 (http:/ucjtk.ff.cuni.cz/wr-content/uploads/sites/57/2015/11/Watson-at-al -prevalence-of-synaesthesia.pdf).

Jiří Zemánek - Milan Grygar (eds), Milan Grygar, Obraz a zvuk, Image and Sound, Praha 1999.

Jaromír Zemina, Via artis, via vitae, Praha 2010. 


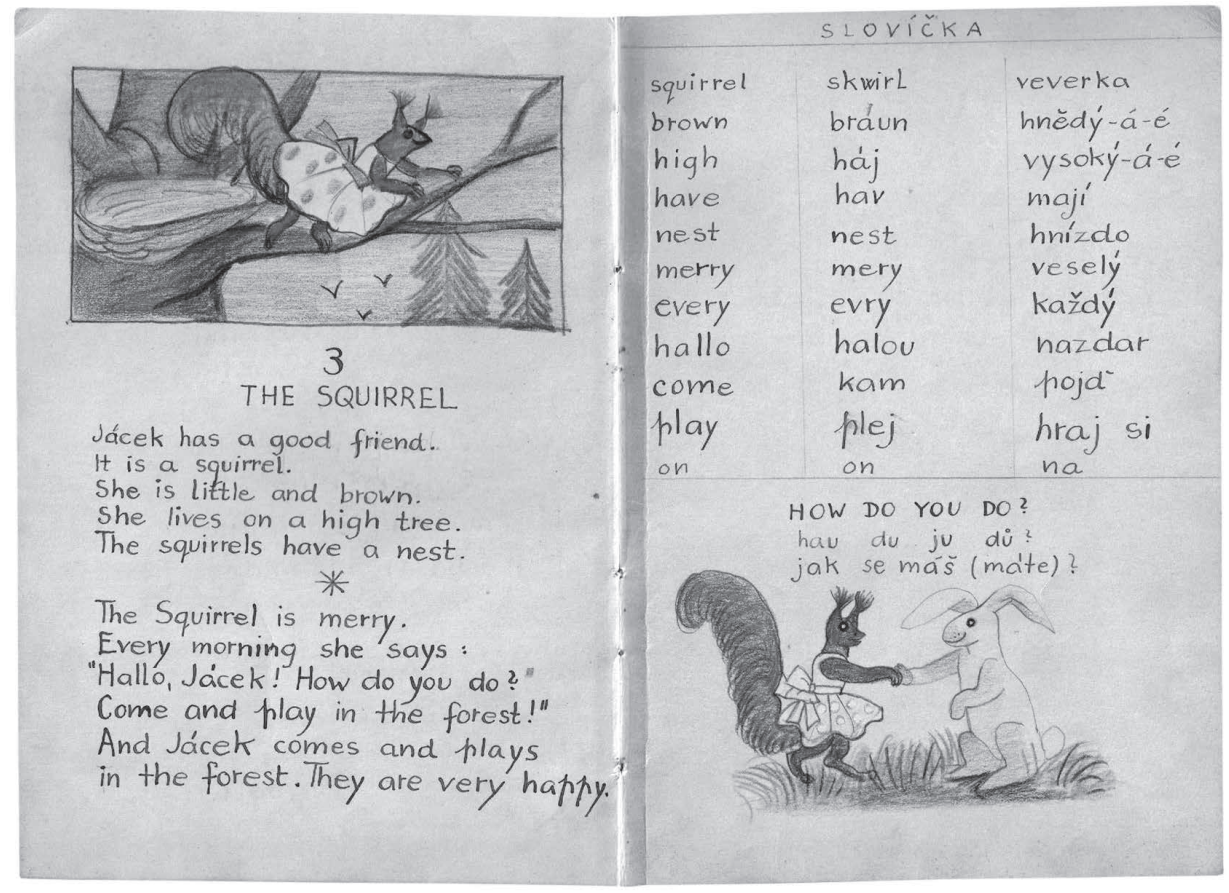

Obrázek 1. Daisy Mrázková, vlastní učebnice angličtiny, neuvedeno. Foto: Markéta Čejková

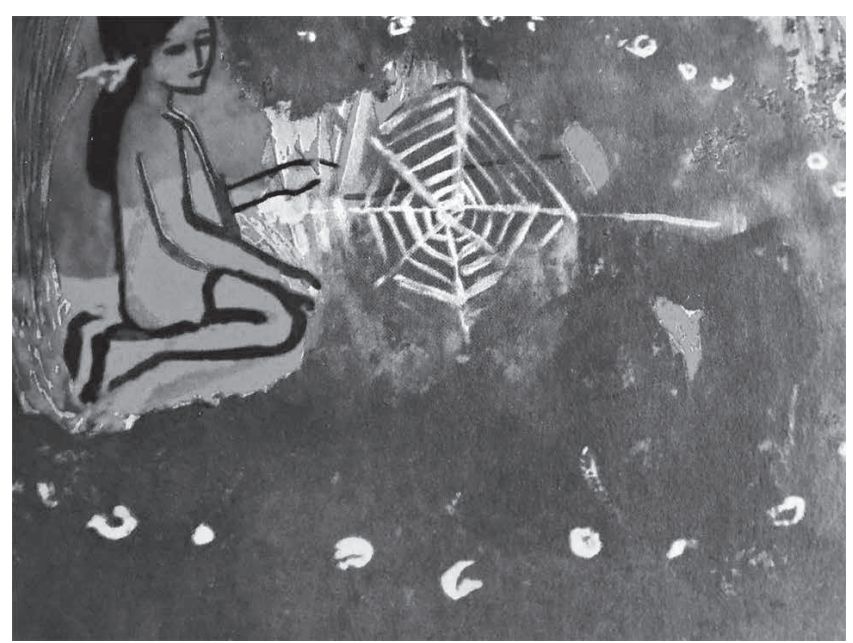

Obrázek 2. Daisy Mrázková, Neplač, muchomůrko, Praha 1965, reprodukce s. 19 


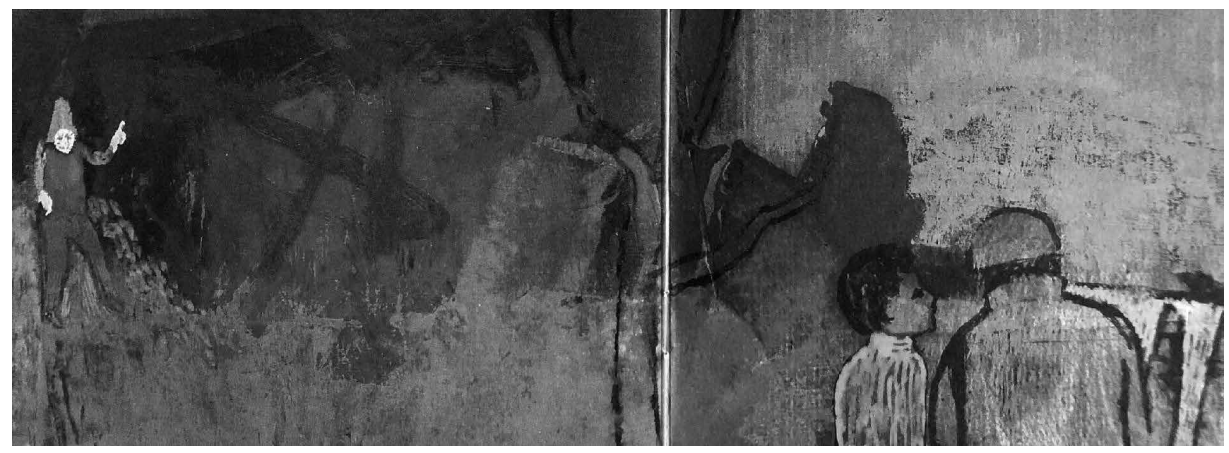

Obrázek 3. Daisy Mrázková, Chlapeček a dálka, Praha 2002, reprodukce s. 18-19

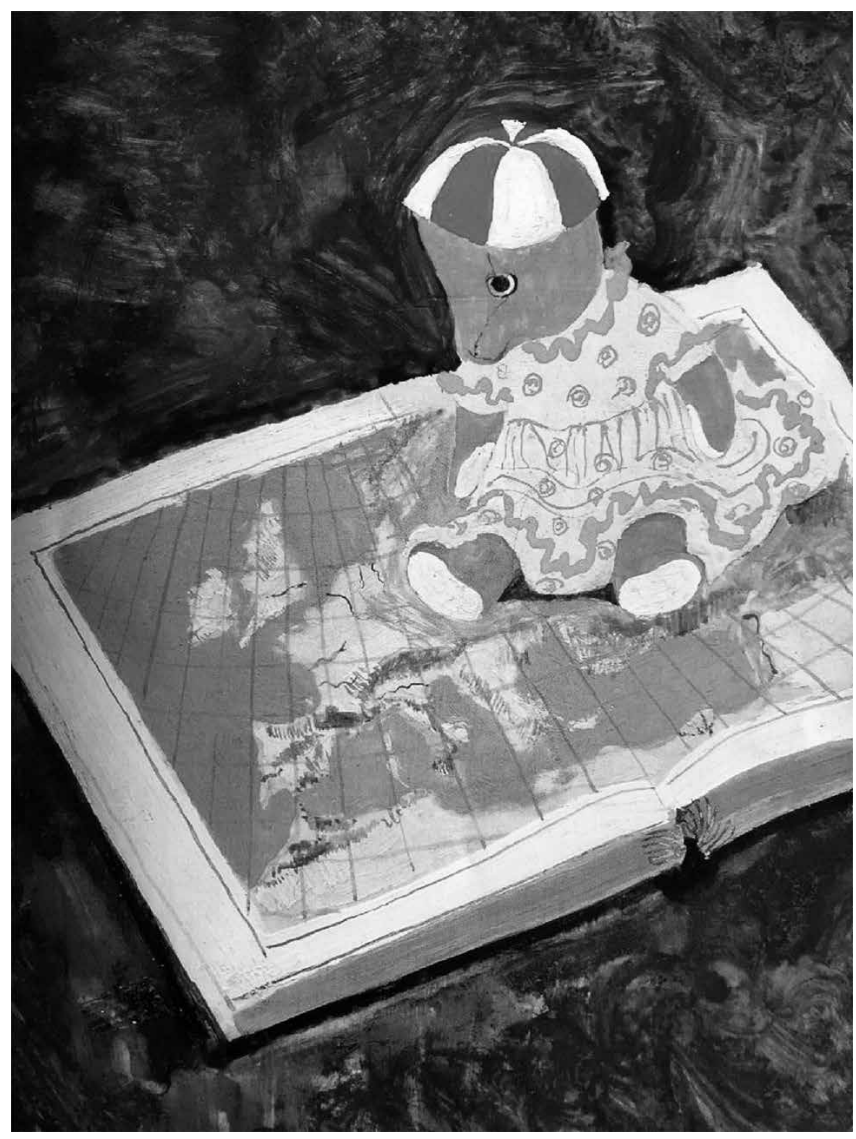

Obrázek 4. Daisy Mrázková, Můj medvěd Flóra, Praha 2002, reprodukce, nepaginováno 